\title{
Chia (Salvia hispanica L.) as a novel forage and feed source: A review
}

\author{
Amir M. Jamshidi, ${ }^{1,2}$ Mariana Amato, ${ }^{2}$ Ali Ahmadi, ${ }^{1}$ Rocco Bochicchio, ${ }^{2}$ Roberta Rossi ${ }^{3}$ \\ ${ }^{1}$ Department of Agronomy and Plant Breeding, University College of Agriculture and Natural Resources, \\ University of Tehran, Karaj, Iran; ${ }^{2}$ School of Agricultural Science, Forestry, Food and Environmental sciences, \\ University of Basilicata, Potenza, Italy; ${ }^{3}$ Council for Agricultural Research and Analysis of Agricultural \\ Economics-Research Centre for Animal Production and Aquaculture, Bella Muro (PZ), Italy
}

\begin{abstract}
Chia (Salvia hispanica L.), is a traditional pre-Colombian food crop from Central America. Being considered the richest botanical source of omega-3 fatty acids, it has recently been rediscovered as a functional food and feed. A growing body of literature indicates that dietary chia seeds greatly improve animal products quality without compromising growth, productivity and organoleptic quality. Chia is mainly cultivated as a seed crop but recently interest has been raised on biomass production as a potential forage source opening alleys toward the integration of chia in crop-livestock systems. Literature on chia is flourishing, up to now reviews addressed botany, agronomy phytochemical and medicinal uses, this article reviews the main findings on chia use in animal nutrition and includes an overview on both seed and biomass yield and quality as affected by environment, agronomy, and genetic background. Chia is a short-day flowering crop, seed yields of commercial varieties can be as high as $2999 \mathrm{~kg} \mathrm{ha}^{-1}$ in areas of origin while at European latitudes seed production is severely hampered by photoperiod sensitivity $\left(\max 518 \mathrm{~kg} \mathrm{ha}^{-1}\right)$. The viable growing of chia for seeds worldwide relies on the availability of genotypes flowering at longer days than in the areas of origin, while for whole plant a relatively high forage yield can be expected. In southern Italy commercial short-day flowering varieties yielded up to $2.07 \mathrm{t} \mathrm{ha}^{-1}$ of leaf dry biomass and in Greece chia yielded up to $15 \mathrm{~T} \mathrm{ha}^{-1}$ dry biomass. Chia seeds supplement in livestock diet are administered with the main objective to increase the content of omega-3 and improve animal health.
\end{abstract}

Correspondence: Roberta Rossi, Council for Agricultural Research and Analysis of Agricultural Economics-Research Centre for Animal Production and Aquaculture, S.S. 7 Via Appia, 85051 Bella Muro (PZ), Italy.

E-mail: roberta.rossi@crea.gov.com

Key words: Chia; crop-livestock systems; feed; forage; omega-3.

Received for publication: 24 June 2018.

Revision received: 25 September 2018.

Accepted for publication: 26 September 2018.

(C) Copyright A.M. Jamshidi et al., 2019

Licensee PAGEPress, Italy

Italian Journal of Agronomy 2019; 14:1297

doi:10.4081/ija.2019.1297

This article is distributed under the terms of the Creative Commons Attribution Noncommercial License (by-nc 4.0) which permits any noncommercial use, distribution, and reproduction in any medium, provided the original author(s) and source are credited.
The majority of work has been done on poultry and rabbits where rewarding results have been obtained in terms of improvement of products lipids profile. Only one work was published on pig but the first results are encouraging. Published data on ruminants are few but in agreement with findings on other species these works demonstrate chia has no adverse effects health performances, and sizeable improvement of milk fatty acid profile. A qualitative improvement of freshwater cultivated fish fillets was also obtained with a partial replacement of soybean oil with chia. Finally an innovative study tested the effect of total or partial replacement of wheat bran in the diets of two edible insects that can be considered the new frontier of food and feed production chains.

\section{Introduction}

Salvia hispanica L. commonly known as Chia, Spanish sage or Mexican Salbia belongs to the genus Salvia of the Lamiaceae family. Chia originated at the low latitudes of Mexico and Guatemala, along with amaranthus, quinoa and maize it was one of the four staple foods of Mayas and Aztech populations (Munoz et al., 2013). After a long oblivion in recent years this crop has been rediscovered, nowadays it is cultivated as a seed crop and used as a functional food and feed. Chia is a source of proteins and secondary metabolites (Ayerza, 2013) among which antioxidants (Ayerza, 2013; Amato et al., 2015) but its popularity can be largely attributed to the exceptionally high content of alpha-linolenic acid (ALA), to the point of being considered one of the richest botanical source of omega-3 (Ayerza and Coates, 2001). Being a short-chain omega-3 fatty acid (FA), ALA is a precursor of longchain (LC) omega-3, which has a major impact on health through many physiological mechanisms. They play a key role for the prevention and treatment of cardiovascular diseases (Nestel et al., 2015; Siscovick et al., 2017) and are very important for the development and maintenance of different organs, primarily the brain and nervous system. Emerging research demonstrated that they could be used as an adjuvant treatment for major depressive disorder (Mocking et al., 2016) as well as for reducing the risk of mood disorders (Berger et al., 2017). Increasing the dietary intake of omega-3 can contribute improve the omega-6: omega-3 ratio whose high values are associated with a greater incidence of cardiovascular disease, cancer, inflammatory and autoimmune diseases (Simopolous, 2008). Optimal values of this ratio should not exceed 4:1 but in western diet values around 20:1 are not uncommon (Simopoulos, 2016). Many animal products are characterised by relatively high levels of saturated fatty acids, and omega6/omega-3 ratio well above 4:1. According to Dalle Zotte and Szendro (2011) this ratio can be as high as 22 in pork loin and in chicken meat (16) while beef and rabbit meat have lower values (9 
and 7 respectively). Several researches proved the causal relationship between animal's products such as red meat and increased incidence of cardiovascular disease, diabetes and some types of cancer (Pan et al., 2012; Abete et al., 2014). Egg industry over the last decade has been penalised by a negative trend in per capita egg consumption possibly linked to the fact that eggs are a major dietary sources of cholesterol and consumers are concerned about the correlation between cholesterol intake and cardiovascular disease (Zazpe et al., 2011). In order to improve the nutritional profile of animal products omega-3 feed enrichment has been extensively investigated in many sectors such as poultry science (Cherian and Sim, 1991; Gonzalez-Esquerra and Leeson, 2001; Fraye et al., 2012), rabbit nutrition (Bernardini et al., 1999; Dal Bosco et al., 2004; Kouba et al., 2008; Peiretti and Meineri, 2010; Dal Bosco et al., 2014) as well as pig nutrition (Morgan et al., 1992; Leskanich et al., 1997). In recent years special attention has also been paid by dairy industries to improve the nutraceutical profile of milk by increasing the content of polyunsaturated fatty acids (PUFA) omega-3 FA (Dewhurst et al., 2006). Ruminants cannot synthesise omega-3 endogenously so their content in milk depends on their proportion in ingested feed and is mediated by rumen bio-hydrogenation processes (Witkowska et al., 2008). Lipid profile in milk can be sharply modified by feeding animals with forages rich in omega-3 (Dewhurst et al., 2003) as well as by supplementing oilseeds or marine oils (Chilliard et al., 2001). In order to improve consumers acceptability industries developed innovative omega-3 fortified animal products that are fuelling an emerging but fastgrowing market worldwide. A list of leading brands for omega-3 fortified animal products in Europe has been reported by Kolanowski and Laufenberg (2006). The necessity of finding botanical sources of omega-3 has even been raised in aquaculture where farmers need to find innovative plant-based feeds as an alternative to overexploited marine sources. According Sprague et al., (2016) in Norwegian salmon farming industry the recent shift from marine to plant-based feeds, with rapeseed oil being one of the most common alternatives to fish oil, has resulted in higher omega-6 levels in fish tissues causing an increase of omega6:omega-3 ratio with consequences on fish nutritional quality. While in this sector much emphasis is placed on the necessity of finding alternative (to marine sources) dietary sources of LC omega-3, salmonids and many freshwater species have complete metabolic pathways to produce LC omega-3 from ALA (Tocher, 2015). Chia is raising so much interest as a nutraceutical food and feed, that books and reviews are appearing, addressing botanical and agronomic aspects (Ayerza and Coates, 2005; Bochicchio et al., 2015a); phytochemistry and pharmacological properties of the seeds (De Falco et al., 2017a), as well as nutritional, functional properties and therapeutic prospects (Valdivia-Lopez and Tecante, 2015; Ulla et al., 2016). There is a growing body of literature on chia seeds use in animal nutrition (Ayerza and Coates, 2000, 2002, 2005, 2006; Ayerza et al., 2002; Azcona et al., 2008; Peiretti and Meineri, 2008) and recently interest has been raised on biomass production as a potential forage source (Peiretti and Gai, 2009; Amato et al., 2015) opening new alleys toward the introduction of chia in forage systems. The aim of present article is to provide a comprehensive account of chia potential as a forage and feed; we therefore address chia use in animal nutrition along with a review of the published works on chia seed and biomass yield and of quality traits relevant to the food chain of animal products, as a function of agronomic management and genetic background. This may serve as a basis to evaluate the feasibility of introducing chia in crop-livestock systems and a short section on future prospects is included.

\section{Botany and history}

Chia (Salvia hispanica L.) is an annual macrothermal crop that belongs to the Lamiaceae family. The centre of origin based on genetic and phenotypic diversity has been identified as the area from Western Mexico to Puebla, with main altitudes between 1400 and $2200 \mathrm{~m}$ a.s.1. (Cahill, 2004). It is generally 60-to-180-cm tall (Capitani et al., 2013), with opposite, petiolate, and serrated leaves; flowers are hermaphrodite and grow in numerous clusters in a spike, and preserved by small bracts with long pointed tips (Ayerza and Coates, 2005). Non-dehiscent dry fruits are routinely named seeds (Capitani et al., 2013) and in domesticated chia mean seed mass is about $1.5 \mathrm{~g} / 1000$ seeds (Cahill and Ehdaie, 2005) (Figure 1). Chia was a staple food of pre-Colombian Central America populations, and was even introduced in Spain after the conquest (Ortiz de Montellano, 1978), but it was dramatically eradicated for the subsequent 500 years following religious conflicts (Ayerza and Coates, 2005). In pre-Columbian Mesoamerica, chia was valued for food use of seeds, medicine and oil (Cahill, 2003), and in recent years several studies have indicated chia as a new oilseed plant due to its high $\omega-3$ fatty acid content, probably the highest among other oilseeds (Cahill, 2003, 2004; Ayerza, 1995, 2011, Ayerza and Coates, 2004, 2007, 2009). Chia is nowadays mainly grown for seeds and commercialised as functional food. However the leaves have potential commercial interest due to their composition (Bushway, 1981) and content of active compounds of nutraceutical, antioxidant and antimicrobial value (Ahmed et al., 1994; Amato et al., 2015; Elshafie et al., 2018). In the last few decades pioneering work by Peiretti and Gai (2009) and Peiretti (2010) has shown the potential of chia seeds as feed and of chia whole plants as functional forage for their content of omega-3.

\section{Seed and biomass yield}

Based on report of Alenbrant et al. (2014), the largest centre of production is Mexico from where seeds are exported to Japan, USA, and Europe. Chia is also grown in Argentina, Bolivia, Colombia, Guatemala, Peru, Australia, Africa, and Southeast Asia (Epling, 1940; Perry and Metzger, 1980; Jansen et al., 1991). Research from Europe (Bochicchio et al., 2015a, 2015b) reports on seed and whole-plant yield.

In the nineties Ayerza and Coates started a study on potential production of chia as an alternative crop in several locations of Argentina and report data from commercial fields or research plots (Coates and Ayerza, 1996, 1998). A large variation in yields (175 to $1602 \mathrm{~kg} \mathrm{ha}^{-1}$ ) can be ascribed to different locations (with corresponding weather conditions) and agronomic practices, and the authors conclude that early sowing affects production greatly and allows to double yields ( $882 \mathrm{~kg} \mathrm{ha}^{-1}$ with early sowing vs 450 and $437 \mathrm{~kg} \mathrm{ha}^{-1}$ for sowings 27 and 46 days later) (Coates and Ayerza, 1996). A more recent study conducted in Ecuador (Ayerza and Coates, 2009) ascertained higher maximum yields (up to $2500 \mathrm{~kg}$ $\mathrm{ha}^{-1}$ ) but still a large variation with location (and corresponding elevation). Out of three chia selections tested in the experiment, Itzac 1 was the most productive. In Ghana Yeboah et al. (2014) showed very high maximum yields (2999 $\mathrm{kg} \mathrm{ha}^{-1}$ ) with high sowing density of 40.000 plants $\mathrm{ha}^{-1}$ and direct sowing, while lower yields were recorded with lower densities and transplanted seedlings. 
Studies at high latitudes in Europe (Amato et al., 2015; Bochicchio et al., 2015b) and Chile (Silva et al., 2016) showed low yields (max $518 \mathrm{~kg} \mathrm{ha}^{-1}$ ) without a significant effect of nitrogen fertilisation (Amato et al., 2015; Bochicchio et al., 2015b) or irrigation (Silva et al., 2016) but with a positive effect of sowing density (Bochicchio et al., 2015b). This was linked to late flowering of chia at high latitudes (Bochicchio et al., 2015b): chia is a selfpollinated short-day flowering plant and the major limiting factor for expanding its cultivation from tropical-subtropical areas to other regions is the temperature and photoperiod sensitivity. At high latitude the crop cannot be sown before late spring and therefore long summer days will delay flowering until early fall and seed maturation will be hampered by low temperatures (Jamboonsri et al., 2012). New chia long-day flowering or photoperiod insensitive mutants were created by Jamboonsri et al. (2012) and some of them were characterised for their yield, agronomic and/or metabolic behaviour at higher latitudes than those of the area of origin (De Falco et al., 2018a, 2018b). A study comparing commercial short-day flowering chia with long-day flowering mutant G8 at high latitude showed low yield regardless of irrigation for the former (less than $300 \mathrm{~kg} \mathrm{ha}^{-1}$ ), whereas G8 yielded up to $2553 \mathrm{~kg} \mathrm{ha}^{-1}$ with a significant response to irrigation (De Falco et al., 2017b). A study stretching across latitudes in Chile (Baginsky et al., 2016) confirmed that high yields (up to $2903 \mathrm{~kg}$ $\mathrm{ha}^{-1}$ ) of short-day flowering chia could be reached at low latitudes whereas lower yields (as low as $70 \mathrm{~kg} \mathrm{ha}^{-1}$ ) are obtained at high latitudes due to late flowering. Some of the studies on seed yield also report plant biomass values at flowering or maturity, and confirm the effect of location and agronomic practices on production with a positive effect of irrigation (Silva et al., 2016) and sowing density (Yeboah et al., 2014; Bochicchio et al., 2015b; Bilalis et al., 2016). Values range from $492 \mathrm{~kg} \mathrm{ha}^{-1}$ reported by Coates and Ayerza (1996) in Argentina to $15,357 \mathrm{~kg} \mathrm{ha}^{-1}$ reported by Bilalis et al. (2016) in Greece. A dry biomass of around $2070 \mathrm{~kg} \mathrm{ha}^{-1}$ of leaves was reported by Amato et al. (2015). It should be noted that late flowering of traditional chia selections at high latitudes might result in vegetative biomass accumulation due to a longer vegetative stage. Therefore a higher biomass and a lower harvest index is reported at higher latitude (Baginsky et al., 2016) in Chile and for commercial short-day flowering chia compared to the long-day flowering mutant G8 at high latitude in Southern Italy (De Falco et al., 2018b). A glasshouse pot study showed a positive effect of arbuscular mycorrhiza inoculation on chia fresh plant biomass (Ouzounidou et al., 2015).

\section{Seed and biomass quality}

According to USDA (2011) chia seeds show high oil content $(30.4 \%)$ but also a remarkable amount of proteins, calcium, and other elements and vitamins (Table 1). Since its rediscovery in the nineties, research on nutrients and active compounds in chia seeds

Table 1. Nutritional composition of chia seed.

\begin{tabular}{lc} 
Nutrient & per $100 \mathrm{~g}$ \\
Energy (kcal.) & 486.00 \\
Proteins (g) & 16.54 \\
\hline Total fat (g) & 30.74 \\
Saturated fatty acids (g) & 3.33 \\
\hline Monounsaturated fatty acids (g) & 2.31 \\
Polyunsaturated fatty acids (g) & 23.67 \\
\hline Trans fatty acids (g) & 0.14 \\
Omega-3 fatty acids (g) & 17.83 \\
\hline Cholesterol (mg) & 0.00 \\
Carbohydrate (g) & 42.12 \\
\hline Fibre, total dietary (g) & 34.40 \\
\hline
\end{tabular}

Source: U.S. Department of Agriculture (2011).

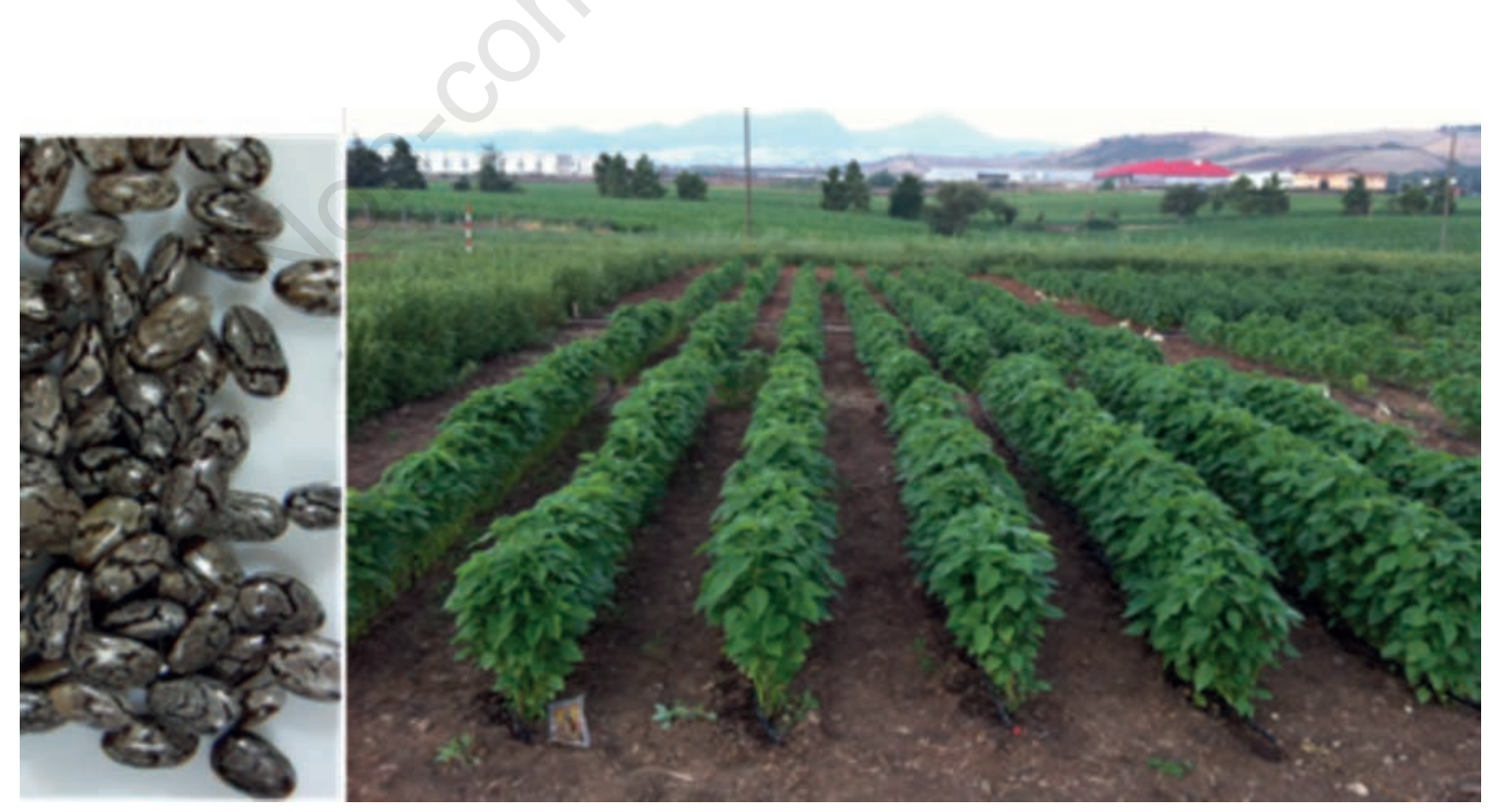

Figure 1. Left: Picture of the non-dehiscent chia dry fruits that are routinely named seeds, in domesticated chia seeds have and average length of $2 \mathrm{~mm}$ and a width of about $1.3 \mathrm{~mm}$, a thousand seeds weights around $1.5 \mathrm{~g}$. Right: frontal view of a chia stand in Southern Italy during vegetative stage, chia has opposite, petiolate, and serrated leaves; height can range between 60 and $180 \mathrm{~cm}$ tall, leaves production can reach 2 tons/ha. 
has been conducted by many authors, but also the composition and more recently the forage quality of chia stems and leaves has been inquired, and seed composition has been found to be affected by factors such as genotype, environment, and agronomical inputs (Ayerza and Coates, 2004; Amato et al., 2015; De Falco et al., 2017b, 2018a, 2018b). Tables 2 and 3 report the main findings on seed and biomass yield as a function of environment, genotype and agronomic practices, Tables 4 and 5 report the current body of knowledge on seed and biomass quality respectively. In the following paragraph a review of available data on quality and yield will be reported for each seed and plant component.

\section{Oil}

Based on many reports, oil content of chia seeds range from 20.30 to $38.60 \%$ (Ayerza, 1995; Ixtaina et al., 2011; Ayerza and Coates, 2004; Da Silva Marineli et al., 2014; Amato et al., 2015). The main fatty acids of chia seed are linolenic acid (18:3), linoleic acid (18:2), stearic acid (18:0), palmitic acid (16:0) and oleic acid (18:1) (Ayerza, 1995; Coates and Ayerza, 1998; Ayerza and Coates, 2004; De Falco et al., 2018b). ALA constitutes the highest percentages (>60\%) (Ayerza, 1995; Coates and Ayerza, 1996; Peiretti and Gai, 2009; Amato et al., 2015; De Falco et al., 2018b). This ALA content is above the percentages reported for other ALA-rich oilseed crops such as flax (Linum usitatissimum L.) (57\%) (Ayerza and Coates, 2004), false flax (Camelina sativa L.) $(48.4 \%)$ (Peiretti and Meineri, 2007), and similar or slightly lower to that of perilla (Perilla frutescens L.) (59.8\% and 60.9\% for chia and perilla respectively) (Ciftci et al., 2012) making chia one of the richest plant-based omega-3 source (Ayerza and Coates, 2001).

Furthermore, chia seeds are known as a good source of vitamins $\mathrm{A}$ and $\mathrm{C}$ and niacin (USDA, 2011). Ecosystem effects on oil content of chia have been reported. A wide range in oil content and fatty acid content of chia seeds grown under various climatic conditions, and in different geographical areas has been shown by Ayerza (1995), Coates and Ayerza (1996, 1998), and Ayerza and Coates (2004). Also oil content can be affected by extraction methods (Ixtaina et al., 2011). Genotype and environmental factors appear to affect the fatty acid composition more than the total oil content as reviewed by Bochicchio et al. (2015a). Specifically, low temperatures (and therefore elevation) positively affect the level of unsaturation of fatty acids in chia as for other oil seed crops (Ayerza, 2009; Ayerza and Coates, 2004, 2011), and therefore oil saturation and the ratio of $\omega-6: \omega-3$ fatty acids decreases with increasing altitude (Ayerza and Coates, 2011). Also, oil content

Table 2. Seed yield.

\begin{tabular}{|c|c|c|c|}
\hline Production area & Experimental factors & Yield & Reference \\
\hline Northwestern Argentina $\left(23^{\circ} 17^{\prime} \mathrm{S}\right.$ to $\left.28^{\circ} 35^{\prime} \mathrm{S}\right)$ & Seeding date and locations & 175 to $1602 \mathrm{~kg} \mathrm{ha}^{-1}$ & Coates and Ayerza, 1996 \\
\hline Northwestern Argentina $\left(24^{\circ} 23^{\prime} \mathrm{S}\right.$ to $\left.25^{\circ} 03^{\prime} \mathrm{S}\right)$ & Geographic locations & 221 to $1262 \mathrm{~kg} \mathrm{ha}^{-1}$ & Coates and Ayerza, 1998 \\
\hline Ecuador $\left(01^{\circ} 18^{\prime} 50^{\prime \prime} \mathrm{S}, 00^{\circ} 03^{\prime} 26^{\prime \prime} \mathrm{S}\right.$, and $\left.00^{\circ} 29^{\prime} 47^{\prime \prime} \mathrm{N}\right)$ & Location and chia selections & 295 to $2300 \mathrm{~kg} \mathrm{ha}^{-1}$ & Ayerza and Coates, 2009 \\
\hline Ghana, Kumasi $\left(06^{\circ} 43^{\prime} \mathrm{N}, 01^{\circ} 36^{\prime} \mathrm{W}\right)$ & Planting methods and planting density & 1754 to $2999 \mathrm{~kg} \mathrm{ha}^{-1}$ & Yeboah et al., 2014 \\
\hline Southern Italy $\left(40^{\circ} 51^{\prime} 37.59^{\prime \prime} \mathrm{N}, 15^{\circ} 38^{\prime} 49.43^{\prime \prime} \mathrm{E}\right)$ & Fertilisation & 182 to $269 \mathrm{~kg} \mathrm{ha}^{-1}$ & Amato et al., 2015 \\
\hline Southern Italy $\left(40^{\circ} 51^{\prime} 37.59^{\prime \prime} \mathrm{N}, 15^{\circ} 38^{\prime} 49.43^{\prime \prime} \mathrm{E}\right)$ & Sowing density $\times$ fertilisation & 134 to $518 \mathrm{~kg} \mathrm{ha}^{-1}$ & Bochicchio et al., 2015a, 2015b \\
\hline Chile $\left(18^{\circ} 30^{\prime} \mathrm{S}\right.$ to $\left.33^{\circ} 30^{\prime} \mathrm{S}\right)$ & Sowing dates and 2 chia phenotypes & 70 to $2903 \mathrm{~kg} \mathrm{ha}^{-1}$ & Baginsky et al., 2016 \\
\hline Northern Chile $\left(30^{\circ} 02^{\prime} 16^{\prime \prime} \mathrm{S}, 70^{\circ} 41^{\prime} 48^{\prime \prime} \mathrm{W}\right)$ & Irrigation $\times$ phenotype & 218 to $381 \mathrm{~kg} \mathrm{ha}^{-1}$ & Silva et al., 2016 \\
\hline Southern Italy $\left(40^{\circ} 51^{\prime} 37.59^{\prime \prime} \mathrm{N}, 15^{\circ} 38^{\prime} 49.43^{\prime \prime} \mathrm{E}\right)$ & $\begin{array}{l}\text { Commercial balck chia vs short-day } \\
\text { flowering mutant } \mathrm{G} 8 \times \text { irrigation regime }\end{array}$ & 110 to $2553 \mathrm{~kg} \mathrm{ha}^{-1}$ & De Falco et al., 2018a \\
\hline
\end{tabular}

Table 3. Biomass yield.

\begin{tabular}{|c|c|c|c|c|}
\hline Plant part & Production area & Experimental factors & Yield & Reference \\
\hline \multirow[t]{7}{*}{$\begin{array}{l}\text { Whole plant } \\
\text { mass }\end{array}$} & $\begin{array}{l}\text { Northwestern Argentina }\left(23^{\circ} 17^{\prime} \mathrm{S} \text { to } 28^{\circ} 35^{\prime} \mathrm{S}\right) \\
\text { Northwestern Argentina }\left(24^{\circ} 23^{\prime} \mathrm{S} \text { to } 25^{\circ} 03^{\prime} \mathrm{S}\right) \\
\text { Ghana, Kumasi }\left(06^{\circ} 43^{\prime} \mathrm{N}, 01^{\circ} 36^{\prime} \mathrm{W}\right)\end{array}$ & $\begin{array}{l}\text { Seeding date and locations } \\
\text { Geographic locations } \\
\text { Planting methods and } \\
\text { planting density }\end{array}$ & $\begin{array}{l}492 \text { to } 3675 \mathrm{~kg} \mathrm{ha}^{-1} \\
1125 \text { to } 4178 \mathrm{~kg} \mathrm{ha}^{-1} \\
1081 \text { to } 2119 \mathrm{~kg} \mathrm{ha}^{-1} \\
\text { fresh } 216 \text { to } 300 \mathrm{~kg} \mathrm{ha}^{-1} \\
\text { dry biomass }\end{array}$ & $\begin{array}{l}\text { Coates and Ayerza, } 1996 \text { bio- } \\
\text { Coates and Ayerza, } 1998 \\
\text { Yeboah et al., } 2014\end{array}$ \\
\hline & Attikis, Greece glasshouse & $\begin{array}{l}\text { Soil } \mathrm{pH} \text { and arbuscular } \\
\text { mycorrhiza inoculation }\end{array}$ & $\begin{array}{l}23 \text { to } 40.2 \text { g plant }^{-1} \\
\text { fresh biomass }\end{array}$ & Ouzounidou et al., 2015 \\
\hline & Southern Italy $\left(40^{\circ} 51^{\prime} 37.59^{\prime \prime} \mathrm{N}, 15^{\circ} 38^{\prime} 49.43^{\prime \prime} \mathrm{E}\right)$ & $\begin{array}{l}\text { Sowing density } x \\
\text { fertilisation }\end{array}$ & $\begin{array}{l}50.87 \text { to } 59.71 \mathrm{t} \mathrm{ha}^{-1} \\
\text { fresh biomass } \\
\left(4.26 \text { to } 5.04 \mathrm{t} \mathrm{ha}^{-1} \text { dry) }\right. \\
\text { before flowering }\end{array}$ & Bochicchio et al., 2015a, 2015b \\
\hline & Northern Chile $\left(30^{\circ} 02^{\prime} 16^{\prime \prime} \mathrm{S}, 70^{\circ} 41^{\prime} 48^{\prime \prime} \mathrm{W}\right)$ & Irrigation $\times$ phenotype & 1830 to $3491 \mathrm{~kg} \mathrm{ha}^{-1}$ & Silva et al., 2016 \\
\hline & Greece $\left(37^{\circ} 59^{\prime} 12^{\prime \prime} \mathrm{N}, 23^{\circ} 42^{\prime} 96^{\prime \prime} \mathrm{E}\right)$ & $\begin{array}{l}\text { Sowing rates and organic } \\
\text { fertilisation }\end{array}$ & 4484 to $15,357 \mathrm{~kg} \mathrm{ha}^{-1}$ & Bilalis et al., 2016 \\
\hline & Chile $\left(18^{\circ} 30^{\prime} \mathrm{S}\right.$ to $\left.33^{\circ} 30^{\prime} \mathrm{S}\right)$ & $\begin{array}{l}\text { Sowing dates and } 2 \text { chia } \\
\text { phenotypes }\end{array}$ & 1854 to $12,415 \mathrm{~kg} \mathrm{ha}^{-1}$ & Baginsky et al., 2016 \\
\hline & Southern Italy $\left(40^{\circ} 51^{\prime} 46.80^{\prime \prime} \mathrm{N}\right)$ & $\begin{array}{l}\text { Commercial chia and long-day } \\
\text { flowering mutants }\end{array}$ & 33.06 to $54.28 \mathrm{~g} /$ plant & De Falco et al., 2018b \\
\hline Leaf biomass & $\begin{array}{l}\text { Southern Italy }\left(40^{\circ} 51^{\prime \prime} 37.59^{\prime \prime} \mathrm{N}, 15^{\circ} 38^{\prime} 49.43^{\prime \prime} \mathrm{E}\right) \\
\text { Southern Italy }\left(40^{\circ} 51^{\prime} 37.59^{\prime \prime} \mathrm{N}, 15^{\circ} 38^{\prime} 49.43^{\prime \prime} \mathrm{E}\right)\end{array}$ & $\begin{array}{l}\text { Sowing density } \times \text { fertilisation } \\
\text { Fertilisation }\end{array}$ & $\begin{array}{l}11 \text { t ha }^{-1} \text { fresh biomass } \\
10.8 \text { t ha }^{-1} \text { fresh biomass, } \\
2.07 \text { dry biomass }\end{array}$ & $\begin{array}{l}\text { Bochicchio et al., 2015a, 2015b } \\
\text { Amato et al., } 2015\end{array}$ \\
\hline
\end{tabular}


Table 4. Seed quality.

\begin{tabular}{|c|c|c|c|}
\hline Production area & Experimental factors & Quality traits & Reference \\
\hline Northwestern Argentina $\left(23^{\circ} 20^{\prime} \mathrm{S}\right.$ to $\left.28^{\circ} 28^{\prime} \mathrm{S}\right)$ & Location & Fatty acids composition & Ayerza, 1995 \\
\hline Northwestern Argentina $\left(23^{\circ} 17^{\prime} \mathrm{S}\right.$ to $\left.28^{\circ} 35^{\prime} \mathrm{S}\right)$ & Seeding date and locations & Fatty acids composition & Coates and Ayerza, 1996 \\
\hline Northwestern Argentina $\left(24^{\circ} 23^{\prime} \mathrm{S}\right.$ to $\left.25^{\circ} 03^{\prime} \mathrm{S}\right)$ & Geographic locations & Oil content and fatty acids composition & Coates and Ayerza, 1998 \\
\hline Glasshouse Israel & Irrigation water & Oil content and fatty acids composition & Heuer et al., 2002 \\
\hline America $\left(4^{\circ} 31^{\prime} \mathrm{S}\right.$ to $\left.28^{\circ} 28^{\prime} \mathrm{S}\right)$ & Location & $\begin{array}{l}\text { Oil and protein content, peroxide index, } \\
\text { fatty acids composition }\end{array}$ & Ayerza and Coates, 2004 \\
\hline Commercial source & Location & $\begin{array}{l}\text { Soluble and insoluble fibres, phenolic } \\
\text { compounds, antioxidant activity }\end{array}$ & Reyes-Caudillo et al., 2008 \\
\hline Commercial source & & Fatty acids composition & Peiretti and Gai, 2009 \\
\hline $\begin{array}{l}\text { Argentina, Bolivia, Ecuador, Tropical rain forest, } \\
\text { Inter-Andean Dry Valley ecosystem } \\
\left(02^{\circ} 18^{\prime} 00^{\prime \prime} \mathrm{S} \text { to } 25^{\circ} 07^{\prime} 48^{\prime \prime} \mathrm{S}, 00^{\circ} 29^{\prime} 47^{\prime \prime}\right. \\
\left.\mathrm{N} \text { to } 00^{\circ} 45^{\prime} 00^{\prime \prime} \mathrm{N}\right)\end{array}$ & Location & $\begin{array}{l}\text { Oil and protein content, fatty } \\
\text { acids composition }\end{array}$ & Ayerza, 2009 \\
\hline $\begin{array}{l}\text { Ecuador }\left(01^{\circ} 18^{\prime} 50^{\prime \prime} \mathrm{S}, 00^{\circ} 03^{\prime} 26^{\prime \prime} \mathrm{S} \text {, }\right. \\
\left.\text { and } 00^{\circ} 29^{\prime} 47^{\prime \prime} \mathrm{N}\right)\end{array}$ & $\begin{array}{l}\text { Location and chia } \\
\text { selections }\end{array}$ & $\begin{array}{l}\text { Oil and protein content, fatty } \\
\text { acids composition }\end{array}$ & Ayerza and Coates, 2009 \\
\hline $\begin{array}{l}\text { Ecuador }\left(00^{\circ} 03^{\prime} 26^{\prime \prime} \mathrm{S} \text { to } 2^{\circ} 18^{\prime} 00^{\prime \prime} \mathrm{S} \text {, }\right. \\
\left.00^{\circ} 47^{\prime} 90^{\prime \prime} \mathrm{N} \text { to } 01^{\circ} 47^{\prime} 90^{\prime \prime} \mathrm{N}\right)\end{array}$ & $\begin{array}{l}\text { Phenotype (seed coat colour) } \\
\text { and growing locations }\end{array}$ & Oil content and fatty acids composition & Ayerza, 2010 \\
\hline Argentina and Guatemala & Two oil extraction methods & $\begin{array}{l}\text { Oil content and quality: fatty acids } \\
\text { composition, colour, carotenoids, } \\
\text { chlorophyll, metals, tocopherols, } \\
\text { polyphenols, oxidative stability rancimat }\end{array}$ & Ixtaina et al., 2011 \\
\hline $\begin{array}{l}\text { America (Argentina }\left(25^{\circ} 07^{\prime} 48^{\prime \prime} \mathrm{S}\right) \text {, } \\
\text { Bolivia }\left(17^{\circ} 17^{\prime} 00^{\prime \prime} \mathrm{S} \text { to } 17^{\circ} 24^{\prime} 00^{\prime \prime} \mathrm{S}\right) \\
\text { and Ecuador }\left(01^{\circ} 18^{\prime} 50^{\prime \prime} \mathrm{S} \text { to } 00^{\circ} 29^{\prime} 47^{\prime \prime} \mathrm{N}\right)\end{array}$ & Location & $\begin{array}{l}\text { Oil and protein content, fatty } \\
\text { acids composition }\end{array}$ & Ayerza and Coates, 2011 \\
\hline Ecuador (Tropical Forest ecosystem) & $\begin{array}{l}\text { Chia seed phenotype } \\
\text { (seed coat colour) and its } \\
\text { composition }\end{array}$ & $\begin{array}{l}\text { Oil and protein content, water \%, } \\
\text { peroxide value, soluble and insoluble fibre, } \\
\text { fatty acids composition, aminoacids } \\
\text { concentration, antioxidant compounds } \\
\text { (flavonols and lignans) }\end{array}$ & Ayerza, 2013 \\
\hline Commercial source & Black chia seed & $\begin{array}{l}\text { Oil and protein content, water \%, ash, } \\
\text { total fibre, oil peroxide and iodine index, } \\
\text { fatty acids tocopherols, phytosterols }\end{array}$ & Alonso-Calderón et al., 2013 \\
\hline Commercial source & Chia seed & $\begin{array}{l}\text { Oil and protein content, water \%, } \\
\text { peroxide value, thiobarbituric acid } \\
\text { reactive substances, DPPH free radical } \\
\text { scavenging activity, ferric reducing } \\
\text { antioxidant power, oxygen radical } \\
\text { absorbance capacity, soluble and } \\
\text { insoluble fibre, fatty acids composition, } \\
\text { antioxidant compounds (polyphenols) }\end{array}$ & Da Silva Marineli et al., 2014 \\
\hline Colima, Mexico & Chia seed & $\begin{array}{l}\text { Phenolics and isoflavones content, } \\
\text { DPPH (2,2-diphenyl-1-picrylhydrazyl) assay }\end{array}$ & $\begin{array}{l}\text { Martínez-Cruz and } \\
\text { Paredes-López, } 2014\end{array}$ \\
\hline Southern Italy $\left(40^{\circ} 51^{\prime} 37.59^{\prime \prime} \mathrm{N}, 15^{\circ} 38^{\prime} 49.43^{\prime \prime} \mathrm{E}\right)$ & Seed source, fertilisation & $\begin{array}{l}\text { Water and oil content, fatty acids } \\
\text { composition, free acidity, peroxide index, } \\
\text { p-anisidine value, chlorophyll, carotenoids, } \\
\text { tocopherol, phenolics, antioxidant activity } \\
\text { Trolox equivalent, oxidative stability Oxitest }\end{array}$ & Amato et al., 2015 \\
\hline Chile $\left(18^{\circ} 30^{\prime} \mathrm{S}\right.$ to $\left.33^{\circ} 30^{\prime} \mathrm{S}\right)$ & $\begin{array}{l}\text { Sowing dates and } 2 \text { chia } \\
\text { phenotypes }\end{array}$ & Oil content and fatty acids profile & Baginsky et al., 2016 \\
\hline Northern Chile $\left(30^{\circ} 02^{\prime} 16^{\prime \prime} \mathrm{S}, 70^{\circ} 41^{\prime} 48^{\prime \prime} \mathrm{W}\right)$ & Irrigation $\times$ phenotype & $\begin{array}{l}\text { Oil content, loinoleoic and alpha-linolenic } \\
\text { fatty acids content }\end{array}$ & Silva et al., 2016 \\
\hline Southern Italy $\left(40^{\circ} 51^{\prime} 37.59^{\prime \prime} \mathrm{N}, 15^{\circ} 38^{\prime} 49.43^{\prime \prime} \mathrm{E}\right)$ & $\begin{array}{l}\text { Chia populations and long-day } \\
\text { flowering mutants, nitrogen } \\
\text { fertilisation }\end{array}$ & $\begin{array}{l}\text { Metabolomic analysis: fatty acids, sugars, } \\
\text { caffeoyl derivatives, flavonoids, organic acids, } \\
\text { free amino acids }\end{array}$ & De Falco et al., 2017b \\
\hline Southern Italy $\left(40^{\circ} 51^{\prime} 37.59^{\prime \prime} \mathrm{N}, 15^{\circ} 38^{\prime} 49.43^{\prime \prime} \mathrm{E}\right)$ & $\begin{array}{l}\text { Commercial black chia vs } \\
\text { long-day flowering mutant } \mathrm{G} 8 \times \\
\text { irrigation regime }\end{array}$ & $\begin{array}{l}\text { Metabolomic analysis, fatty acids, sugars, } \\
\text { caffeoyl derivatives, flavonoids, organic acids, } \\
\text { free amino acids, phenolics, antioxidant activity } \\
\text { Trolox equivalent }\end{array}$ & $\begin{array}{l}\text { De Falco et al., 2018a } \\
\text { y }\end{array}$ \\
\hline
\end{tabular}


and fatty acids composition are affected by chia selection (Ayerza and Coates, 2009), sowing date (Coates and Ayerza, 1996; Baginsky, 2016), and salinity of irrigation water (Heuer et al., 2002). No difference was found in oil content and composition between chia phenotypes by Ayerza (2010), but Silva et al. (2016) found a higher content of omega-3 in white chia compared to the black phenotype, and De Falco et al. (2018b) found a higher content of omega-3 in a white chia phenotype compared to black chia and long-day flowering mutants. Also, De Falco et al. (2018a) found a higher content of omega 3 in the long-day flowering mutant G8 compared to a commercial black chia, both grown in southern Italy. Irrigation was not found to affect oil content by Silva et al. (2016) and De Falco et al. (2018a), but it changed the composition of fatty acids and increased omega- 3 and reduced the oleic/linoleic ratio from 47.4 in rainfed plots to 39.6 in irrigated plots. Peiretti and Gai (2009) investigated vegetative parts of chia and found a content of fats decreasing from $30 \mathrm{~g} \mathrm{~kg}^{-1}$ at the early vegetative stage to $18 \mathrm{~g} \mathrm{~kg}^{-1}$ at the budding stage. The percentage of polyunsaturated fatty acids was high and decreased from $752 \mathrm{~g}$ $\mathrm{kg}^{-1}$ to $623 \mathrm{~g} \mathrm{~kg}^{-1}$ of the total plant fatty acids during plant growth. The most abundant fatty acid was alpha-linolenic acid, but its proportion to other fatty acids varied from a maximum of $649 \mathrm{~g} \mathrm{~kg}^{-1}$ at early vegetative and $499 \mathrm{~g} \mathrm{~kg}^{-1}$ at budding. According to Ouzounidou et al. (2015) fat content and composition in chia leaves is affected by soil ph and inoculation with arbuscular mycorrhiza.

\section{Protein}

According to Ayerza and Coates $(2004,2009,2001)$ chia seeds have high levels of protein (16-26\%, depending on environment), compared to cereal seeds or oilseeds, even though chia is not commercially grown as a protein source around the World. Values will also change under different agronomic, climatic and soil conditions (Ting et al., 1990). Ayerza and Coates (2004) report a variation in protein content of chia seeds from locations in four different countries but could not totally explain it with environmental factors. Chia seed protein has nine essential amino acids (Ayerza, 2013), with more balanced composition in comparison with other grains (Ayerza and Coates, 2001) especially with regard to cysteine and methionine (Ixtaina et al., 2008; Sandoval-Oliveros and Paredes-López, 2013). Crude protein content in vegetative parts of the plant have been studied by Peiretti and Gai (2009) and Peiretti (2010), who reported values decreasing from $188 \mathrm{~g} \mathrm{~kg}^{-1}$ at the early vegetative stage to $57 \mathrm{~g} \mathrm{~kg}^{-1}$ at budding. According to Bilalis et al. (2016) crude protein in chia biomass increases with manure fertilisation $v s$ other organic fertilisers, and with narrow row spacing. Ouzounidou et al. (2015) report a variation in plant protein content according to soil $\mathrm{pH}$ and inoculation with arbuscular mycorrhiza.

\section{Fibre}

Recent studies have shown that total dietary fibre content in the chia seed ranges between 32.4 and $37.50 \mathrm{~g} / 100 \mathrm{~g}$, most of

Table 5. Biomass quality.

\begin{tabular}{|c|c|c|c|c|}
\hline Plant part & Production area & Experimental factors & Quality traits & Reference \\
\hline Whole plant & Karad, India & $\begin{array}{l}\text { Different levels of ethanolic } \\
\text { extracts of chia }\end{array}$ & Anthelmintic efficacy & Patil et al., 2014 \\
\hline Stem and leaves & Po valley, Northern Italy & Plant growth stage & $\begin{array}{l}\text { Fatty acids composition, dry matter, } \\
\text { organic matter, crude protein, } \\
\text { ether extract, ash, acid detergent } \\
\text { fibre and neutral detergent fibre, } \\
\text { lignin, in vitro organic matter digestibility, } \\
\text { gross energy }\end{array}$ & Peiretti and Gai, 2009 \\
\hline Stem and leaves & Po valley, Northern Italy & $\begin{array}{l}\text { Herbage and silage according } \\
\text { to plant growth stage }\end{array}$ & $\begin{array}{l}\text { Herbage composition and ensilability } \\
\text { characteristics: dry matter, water soluble } \\
\text { carbohydraytes content, pH, buffering capacity, } \\
\text { soluble and total nitrogen, gross energy, } \\
\text { alcohol, volatile fatty acids, lactic acid }\end{array}$ & Peiretti, 2010 \\
\hline Stem and leaves & $\begin{array}{l}\text { Greece }\left(37^{\circ} 59^{\prime} 12^{\prime \prime} \mathrm{N}\right. \\
\left.23^{\circ} 42^{\prime} 96^{\prime \prime} \mathrm{E}\right)\end{array}$ & $\begin{array}{l}\text { Sowing rates and organic } \\
\text { fertilisation }\end{array}$ & $\begin{array}{l}\text { Dry matter, organic matter, crude protein, } \\
\text { ether extract, ash, acid detergent fibre and } \\
\text { neutral detergent fibre }\end{array}$ & Bilalis et al., 2016 \\
\hline Stem and leaves & $\begin{array}{l}\text { Italy, Southern Italy } \\
\left(40^{\circ} 51^{\prime} 37.59^{\prime \prime} \mathrm{N}\right. \\
\left.15^{\circ} 38^{\prime} 49.43^{\prime \prime} \mathrm{E}\right)\end{array}$ & $\begin{array}{l}\text { Long-day flowering mutant } \\
\text { genotype (G8) }\end{array}$ & $\begin{array}{l}\text { Composition of essential oils, fungicidal } \\
\text { and bactericidal assays }\end{array}$ & Elshafie et al., 2018 \\
\hline Leaves & $\begin{array}{l}\text { Southern California, } \\
\text { South-eastern Texas, } \\
\text { and Northwestern } \\
\text { Argentina }\end{array}$ & Location & Composition of essential oils & Ahmed et al., 1994 \\
\hline Leaves & $\begin{array}{l}\text { Southern Italy } \\
\left(40^{\circ} 51^{\prime} 37.59^{\prime \prime} \mathrm{N},\right. \\
\left.15^{\circ} 38^{\prime} 49.43^{\prime \prime} \mathrm{E}\right)\end{array}$ & Fertilisation & $\begin{array}{l}\text { Metabolomics of methanol extract: } \\
\text { flavonoids and hydroxycinnamic acid } \\
\text { derivatives }\end{array}$ & Amato et al., 2015 \\
\hline $\begin{array}{l}\text { Stems, leaves } \\
\text { and roots }\end{array}$ & Attikis, Greece & $\begin{array}{l}\text { Soil pH and arbuscular mycorrhiza } \\
\text { inoculation }\end{array}$ & $\begin{array}{l}\text { Oil, protein and carbohydraye content, } \\
\text { fatty acids composition and phenolics of plant } \\
\text { shoots, content of P in roots and shoots }\end{array}$ & Ouzounidou et al., 2015 \\
\hline
\end{tabular}


which is insoluble ( $>93 \%)$ and the rest soluble $(<7 \%)$ (ReyesCaudillo, 2008; da Silva Marineli et al., 2014). Chia meal has a high level of dietary fibre (33.9-39.9\% of dietary fibre per $100 \mathrm{~g}$ ) according to Capitani et al. (2012), and therefore it has a high potential for human and animal nutrition (Ting et al., 1990). Numerous studies have shown the effect of potential health benefit of chia seed fibre consumption in some disease such as coronary heart disease, risk for diabetes type 2, and cancer (Steinmetz and Potter, 1996; Lattimer et al., 2010; Kaczmarczyk et al., 2012). Part of the chia dietary fibre is located in the epidermal cells of the seed and it swells when hydrated (Valdivia-López and Tecante, 2015), forming a mucilage capsule around the seed. This mucilage may be extracted (Muñoz et al., 2012). The content of surface mucilage is 5 to $10 \%$ (Munoz et al., 2012; Reyes-Caudillo et al., 2008; Ayerza and Coates, 2001). Health benefits of chia seed mucilage are reviewed by De Falco et al. (2017a) and are mainly related to the control of health in the digestive system and obesity, with related coronary disease. The mucilage extracted from chia seeds has an excellent potential in food technology as a thickener (Munoz et al., 2012), it can be used as a basis for films to avoid food dehydration (Capitani et al., 2015, 2012; Muñoz et al., 2012), as a replacement for fat in cakes (Felisberto et al., 2015), and as an additive to improve rheology and nutraceutical properties of gluten-free pasta (Menga et al., 2017). Rheological and physico-chemical effects of the mucilage in soil have also been explored by Di Marsico et al. (2018a, 2018b), who showed a dose- and soil-dependent significant increase in soil aggregate stability and changes in soil porosity and herbicide-soil interactions.

\section{Antioxidants and other compounds}

Besides fatty acids, In addition to fatty acids composition, protein and fibre, chia seed has other important ingredients as natural antioxidants, which have beneficial influence on human health (Nijveldt et al., 2001). These compounds have been reviewed by De Falco et al. (2017a) and include phenolic contents such as chlorogenic acid, caffeic acid, myricetin, quercetin, kaempferol and 3, 4-dihydroxyphenylethanol-elenolic acid dialdehyde (3, 4DHPEA-EDA), and tocopherols, phytosterols, lignans and carotenoids (Reyes-Caudillo et al., 2008; Ayerza, 2013; AlonsoCalderón et al., 2013; Martínez-Cruz and Paredes-López, 2014; Da Silva Marineli et al., 2014; Amato et al., 2015; De Falco et al., 2017b, 2018a, 2018b). Health benefits of such compounds have been identified (Ayerza and Coates, 2005; Vuksan et al., 2007) and reviewed by De Falco et al. (2017a). No evidence of allergic and toxic effects upon consumption has been reported (EFSA, 2009). Several authors report a rather high antioxidant capacity or oxidative stability of chia seeds (Reyes Caudillo et al., 2008; Ixtaina et al., 2011; Coelho and de las Mercedes Salas-Mellado, 2014; Da Silva Marineli et al., 2014; Martínez-Cruz and Paredes-López, 2014; Amato et al., 2015; De Falco et al., 2018a, 2018b). According to Amato et al. (2015) fertilisation with inorganic $\mathrm{N}$ resulted in an increase of free acidity, chlorophyll and carotenoids, whereas it reduced $p$-anisidine value, phenols and oxidative stability. A series of metabolomic studies of chia seeds comparing traditional sources such as commercial black and white chia with longday flowering mutants were performed by De Falco et al. (2017b, 2018a, 2018b). They report that apolar organic extracts were mainly composed of mono- and polyunsaturated fatty acids and polar organic extracts contained sugars such as glucose, raffinose, sucrose, methylgalactoside as well as caffeoyl derivatives, flavonoids, organic acids, free amino acids. De Falco et al. (2017b) reported Tashinone I and 15, 16 dihy-dro Tanshinone I in chia seeds for the first time. The metabolic fingerprinting of different chia sources showed that black phenotypes are richest in carbohydrates, white chia in omega-3 (De Falco et al., 2017b) and according to De Falco et al. (2018b) long-day flowering mutants G17 and G8 are rich in nutraceuticals (such as quinic acids, caffeic acid and others). According to De Falco et al. (2018a) mineral nitrogen topdressing increased the content of aliphatic free amino acids, and decreased the level of carbohydrates and flavonoids, but not caffeoyl derivatives, organic and fatty acids. They also report a higher content in polyphenols in long-day flowering mutants compared to commercial black and white chia, and this was related with the level of total polyphenols but not with the content of other antioxidants such as malic, citric and quinic acids. Ahmed et al. (1994) identified fifty-two different compounds in chia leaves, and report that the major component detected in essential oils was Pcaryophyllene. Elshafie et al. (2018) found more than eighty compounds in essential oils from vegetative parts of chia with caryophyllenes as the main components and $1.5 \%$ of phenolic compounds. Amato et al. (2015) identified thirty-four compounds in methanol extracts of chia vegetative parts. Among them several flavonoids and hydroxycinnamic acids. They found two uncommon flavonoids (acetyl vitexin and acetyl orientin) not previously reported in Lamiaceae.

\section{Minerals and vitamins}

Chia seed besides other main ingredients is a great source of some nutritional components like minerals and vitamins. So that, early researches are related to content of vitamin B in seeds (Bushway et al., 1984). Chia fruits have a high level of vitamin B (Bushway et al., 1984) compared with most other cereals. Also it is excellent source for minerals as calcium, phosphorus, potassium, zinc and copper (Ayerza, 2001). According to recent evidence, macronutrients concentration of chia seeds are phosphorus 860, calcium 631, potassium 407, and magnesium $335 \mathrm{mg} / 100 \mathrm{gm}$, and microelements; selenium 55.2, sodium 16, iron 7.72, manganese 2.72, zinc 4.58, copper 0.924 , molybdenum $0.2 \mu \mathrm{g} / 100 \mathrm{~g}$ (Ullah et al., 2016). Phosphorous, calcium and potassium content of chia seed is more than other crops such as wheat, rice, oats and corn (Beltran-Orozco and Romero, 2003).

\section{Chia in animal nutrition}

The use of chia in animal nutrition until now has been limited to the use of seeds, either raw or processed (grinding/pelleting) and oil, and to the use of by-products such as discarded seeds and seed meal. The main objective has been increasing the content of omega-3 fatty acids of animal products. So far chia dietary use has been tested on monogastric (rabbits, pigs, broilers, hens and quails), on ruminants (on dairy cows and goats, and for lamb fattening), on fishes (freshwater aquaculture) and recently on edible insects (Table 6). As mentioned above chia is mainly grown as a seed crop, recently though whole plant or leaf biomass has been proposed as forage, because of useful and health-promoting compounds in vegetative tissues (Ahmed et al., 1994; Peiretti and Gai, 2009; Peiretti, 2010; Amato et al., 2015). There are no reports on the effect of whole plant use in animal diets. Therefore the following paragraphs will report the key findings of the published feeding trials followed by a section on the perspective forage use and a brief overview of other potential uses in livestock systems.

\section{Chia use in poultry science}

As shown in Table 6 the largest number of studies on chia use 
Table 6. Feeding trials.

\begin{tabular}{|c|c|c|c|c|c|}
\hline Animal & Feed ingredient & Inclusion rate (w/w) & $\begin{array}{l}\text { Experiment } \\
\text { duration }\end{array}$ & Evaluated parameters & Reference \\
\hline \multicolumn{6}{|c|}{ Monogastrics Poultry } \\
\hline \multirow[t]{7}{*}{ Laying hens } & Whole seed & $0,30 \%$ & 4 weeks & $\begin{array}{l}\text { Egg yield, FA profile, } \\
\text { cholesterol content, } \\
\text { organoleptic profile }\end{array}$ & Ayerza and Coates, 1998 \\
\hline & Whole seed & $0,7,14,21,28 \%$ & 90 days & $\begin{array}{l}\text { Egg yield, cholesterol content, } \\
\text { eggs FA profile }\end{array}$ & Ayerza and Coates, 2000 \\
\hline & Whole seed & $\begin{array}{l}\text { Chia-flax combination: } \\
\text { 0-0, 7-3, 9-5, 11.5-2.5,14-0 } \\
\text { chia flax respectively }\end{array}$ & 30 days & $\begin{array}{l}\text { Egg yield, FA profile, cholesterol } \\
\text { content, organoleptic profile }\end{array}$ & Ayerza and Coates, 2001 \\
\hline & Whole seed & $0,7,14,21,28 \%$ & 90 days & $\begin{array}{l}\text { Hen weight, egg production, } \\
\text { egg weight, and yolk weight } \\
\text { and percentage }\end{array}$ & Ayerza and Coates, 2002 \\
\hline & Whole seeds & $0,7.5,15.0 \%$ & 16 weeks & $\begin{array}{l}\text { Productive performance and } \\
\text { lipid composition of the egg yolk } \\
\text { and body tissues }\end{array}$ & Salazar-Vega et al., 2009 \\
\hline & Whole seed and chia oil & $0,25 \%$ chia seed, $6 \%$ oil & 84 days & $\begin{array}{l}\text { Production performance, egg yolk, } \\
\text { total fat and fatty acid composition }\end{array}$ & Antruejo et al., 2011 \\
\hline & Whole seed grinded & $0,20,30,40 \%$ & 5 weeks & $\begin{array}{l}\text { Fat content and fatty acid } \\
\text { composition of egg yolk and sensory } \\
\text { attributes }\end{array}$ & Coorey et al., 2015 \\
\hline Laying quails & Whole seed grinded & $0,5,7.5 \%$ & 4 weeks & $\begin{array}{l}\text { Egg fatty acid profile, short to } \\
\text { long-chain omega-3 FA bioconversion } \\
\text { efficiency }\end{array}$ & Komprda et al., 2013 \\
\hline \multirow[t]{4}{*}{ Broiler } & Whole seed & $0,10,20 \%$ & 7 weeks & $\begin{array}{l}\text { White and dark meat fatty acid profile, } \\
\text { broilers productive performance, } \\
\text { sensory attributes }\end{array}$ & Ayerza et al., 2002 \\
\hline & Whole seed and chia meal & $0,15 \%$ & 46 days & $\begin{array}{l}\text { Productive performances, } \\
\text { meat fatty acid profile }\end{array}$ & Azcona et al., 2008 \\
\hline & Whole seed & $0,5,10 \%$ & 6 weeks & Growth performance and body tissues & Salazar-Vega et al., 2009 \\
\hline & Whole seed grinded & $0,3,6,9 \%$ & 6 weeks & $\begin{array}{l}\text { Meat fatty acid profile, long-chain } \\
\text { omega-3 FA deposition }\end{array}$ & Komprda et al., 2013 \\
\hline \multicolumn{6}{|c|}{ Monogastrics } \\
\hline \multirow[t]{4}{*}{ Rabbit } & $\begin{array}{l}\text { Whole seed pelleted } \\
\text { Whole seed pelleted }\end{array}$ & $\begin{array}{l}0,10,15 \% \\
0,10,15 \%\end{array}$ & $\begin{array}{l}35 \text { days } \\
35 \text { days }\end{array}$ & $\begin{array}{l}\text { Apparent feed digestibility } \\
\text { Growth performance, carcass } \\
\text { parameters, meat FA composition }\end{array}$ & $\begin{array}{l}\text { Meineri and Peiretti, } 2007 \\
\text { Peiretti and Meineri, } 2008\end{array}$ \\
\hline & Whole seed pelleted & $0,10,15 \%$ & 5 weeks & $\begin{array}{l}\text { Meat quality, oxidative stability } \\
\text { and sensory traits }\end{array}$ & Meineri et al., 2010 \\
\hline & Seed oil & & 5-6 weeks & $\begin{array}{l}\text { Vascular function in } \\
\text { hypercholesterolaemic animals }\end{array}$ & Sierra et al., 2015 \\
\hline & Discarded seed & $0,10,20,30,40 \%$ & 6 weeks & $\begin{array}{l}\text { Growth, energy, and economic } \\
\text { efficiency }\end{array}$ & Rodríguez-Abello et al., 2016 \\
\hline Pig & Whole seed & $0,10,20 \%$ & 63 days & $\begin{array}{l}\text { Productive performances, FA profile } \\
\text { of subcutaneous and perineal fat deposits, } \\
\text { sensory analysis }\end{array}$ & Coates and Ayerza, 2009 \\
\hline \multicolumn{6}{|l|}{ Ruminants } \\
\hline Dairy cow & Whole seed & $0,17.5 \%$ & 94 days & $\begin{array}{l}\text { Total fat content, cholesterol content, } \\
\text { and FA composition of milk }\end{array}$ & Ayerza and Coates, 2006 \\
\hline \multirow[t]{2}{*}{ Dairy goat } & Discarded seed & $\begin{array}{l}100 \% \text { maize concentrate } \\
\text { replacement }\end{array}$ & 5 weeks & $\begin{array}{l}\text { Milk yield, milk gross properties, } \\
\text { FA profile }\end{array}$ & Martinez, 2013 \\
\hline & Whole seed & $0,2.7,5.5 \%$ & 20 days & $\begin{array}{l}\text { Feed intake, digestibility, milk FA profile } \\
\text { in vitro gas production }\end{array}$ & Schettino et al., 2017 \\
\hline \multirow[t]{3}{*}{ Lamb } & Whole seed & $0,10 \%$ & $\begin{array}{l}\text { From } 16 \text { to } \\
27 \mathrm{~kg} \text { live } \\
\text { weight }\end{array}$ & $\begin{array}{l}\text { Meat FA composition, sensory } \\
\text { analysis }\end{array}$ & Insausti et al., 2011 \\
\hline & Whole seed & $\begin{array}{l}0,10 \%, 10 \% \text { chia } \\
+10 \% \text { flax }\end{array}$ & $\begin{array}{l}\text { Initial weight } \\
\text { not specified, } \\
\text { slaughtered at } \\
27 \mathrm{~kg} \text { live weight }\end{array}$ & Growth and carcass parameters & Mendizabal et al., 2011 \\
\hline & Whole seed & $0,10 \%$ & 4 weeks & $\begin{array}{l}\text { Growth, carcass parameters, FA profile, } \\
\text { regulation of genes lipogenesis }\end{array}$ & Urrutia et al., 2015 \\
\hline
\end{tabular}


in animal nutrition were published in the area of poultry science, which also show the largest variability in terms of seed products: materials range from whole seed - the most common type of supplementation - to chia flour and oil. Also in this area a few trials compared the effects of chia addition with other common sources of omega-3 such as linseed. So far toxicity or increased mortality have never been reported, even when chia seeds simply replaced a portion of control diet on dry matter basis. Ayerza and Coates (1999) showed that a $30 \%$ inclusion (without balancing protein/energy supply among diets) slightly reduced total egg yield (from 11.57 of control to 10.36 eggs day ${ }^{-1}$ of chia diets, values averaged across dates) but greatly improved egg FA profile by reducing saturated fatty acids and increasing omega-3 content, no increased mortality was found. Palmitic fatty acid content of yolks was significantly reduced with the chia diet $(\mathrm{P}<0.05)$, after 4 weeks of supplementation the concentration was reduced by up to $35 \%$. On average no significant effects on yield cholesterol were found but there was a tendency for a higher cholesterol content in the eggs produced by chia-fed animals; as commented by the authors this increase possibly reflects the different oil content of the two diets $(6.67 \%$ vs $14.5 \%$ of control and chia diet respectively). ALA content was greatly increased (on average from 0.28 to $12.72 \%$ in the chia group), omega- 3 to omega- 6 ratio increased from 0.01 of control to 0.58 in the chia group. According to these authors with basis on scientific literature on linseed supplementation, chia seems more efficient than linseed in reducing saturated fatty acids. They conclude that chia supplementation could contribute to reverse the declining per capita consumption of eggs and egg products occurring in recent years thanks to improvements in egg nutritional profile without affecting organoleptic quality. A slight egg yield reduction was also reported by Salazar-Vega et al. (2009) when 7.5 and $15.0 \%$ chia inclusion were supplemented for 16 weeks to Babcock laying hens in comparison with a standard diet, in their case though egg weight increased with chia increase. ALA proportion increased significantly with increasing chia content (respectively $0 \%$ under control diet and 1.9 and $4.4 \%$ for the 7.5 and $15 \%$ inclusion), no significant differences between chia groups were detected. Chia did not modify linoleic acid or monounsaturated FA content, only at $15 \%$ inclusion level there was a slight reduction in C16:0. Consistent with the other studies reported here cholesterol content did not change. Another study showed that dietary chia effect on productive performances vary with the breed (Ayerza and Coates, 2000). Two breeds white and brown commercial strains (developed from White Leghorn and Red Sex Link breeds respectively) were fed 90 days with diets containing $0,70,140,210$ and $280 \mathrm{~g} / \mathrm{kg}$ whole chia seed. In both strains chia did not affect hens weight and greatly improved lipid profile. Chia reduced yolk cholesterol content in white hens (this parameters was not measured on brown hens), from 1.01 of control diet to $0.93 \%$ at $28 \%$ inclusion. Docosahexanoic acid (DHA) was significantly higher $(\mathrm{P}<0.05)$ in in chia groups. As reported by the authors white hens fed the $7,14,21$, and $28 \%$ chia diets gave an average increase in omega-3 fatty acid content of 658, 1059, 1310 and $1659 \%$ as compared to brown hens whose eggs omega- 3 content increased by $670,1099,1375$ and 1682 in comparison with control diet. A significant $(\mathrm{P}<0.05)$ egg yield reduction though was observed in white hens at same dates $(12 \%$ of total cases) in animals fed with the highest chia dose (21 and 28\%), this lower production was coupled with a reduction of egg weight indicating that the $21 \%$ chia inclusion can be considered an upper limit for this breed. On the opposite chia increased egg weight for brown hens. With an average egg weight $65.75 \mathrm{~g}$ (no significant differences between chia diets). This way eggs produced by brown hens met the extra-large grade requirements (eggs weight $>62 \mathrm{~g}$ ) of Argentina egg market and no detrimental effects on organoleptic effect was observed. Interestingly in poultry science for the first time three studies compared chia dietary effect with linseed that is one of the most common plant-based omega-3 sources in livestock science (Ayerza and Coates, 2001; Antruejo et al., 2012; Coorey et $a l ., 2015)$. Ayerza and Coates (2001) tested the effect of 5 combinations of chia and flaxseed $(0-0,7-3,9-5,11.5-2.5,14-0 \%$ of chia and linseed respectively). Overall oilseed enrichment did not change egg yield and cholesterol content but improved FA profile. When the total inclusion rate (chia + linseed) reaches $14 \%$, palmitic acid content decreased and monounsaturated and polyunsaturated FA both increased $(\mathrm{p}<0.05)$. Oilseed inclusion decreased dramatically omega-6:omega-3 ratio, no significant differences were found among enriched diet. In general though the higher the chia content the lower the omega-6: omega-3 ratio that for the yolk ranged between 11.30 for the control diet to 1.76 for the $14 \%$ chia diet .The diet with the highest level of flaxseed $(5 \%)$ reduced hens weight but yielded a significantly higher proportion of long-chain omega-3 DHA compared to the other chia diets and the control $(p<0.05)$. The taste panel showed that the diet with the highest lin-

Table 6. Continued from previous page.

\begin{tabular}{|c|c|c|c|c|c|}
\hline Animal & Feed ingredient & Inclusion rate $(w / w)$ & $\begin{array}{l}\text { Experiment } \\
\text { duration }\end{array}$ & Evaluated parameters & Reference \\
\hline \multicolumn{6}{|l|}{ Fishes } \\
\hline \multirow[t]{3}{*}{ Nile tilapia } & Whole seed grinded & $0,5 \%$ & 45 days & $\begin{array}{l}\text { Growth performances, lipid composition, } \\
\text { FA profile }\end{array}$ & Silva et al., 2014 \\
\hline & Seed oil & $0,0.63 \%$ & 60 days & $\begin{array}{l}\text { Lipid composition and antioxidant } \\
\text { capacity evaluation }\end{array}$ & Carbonera et al., 2016 \\
\hline & $\begin{array}{l}\text { Chia oil alone or blended } \\
\text { with avocado peel extract }\end{array}$ & $\begin{array}{l}0,1.9 \%, 1.9 \%+0.14 \% \\
\text { avocado extract }\end{array}$ & 45 days & $\begin{array}{l}\text { Growth performances, meat FA profile, } \\
\text { feed antioxidant capacity }\end{array}$ & Montanher et al., 2016 \\
\hline \multicolumn{6}{|c|}{ Edible insects } \\
\hline Cricket & Whole seed grinded & $0,50 \%, 100 \%$ & 10 days & FA profile & Komprda et al., 2013 \\
\hline $\begin{array}{l}\text { Giant } \\
\text { mealworm } \\
\text { beatle }\end{array}$ & Whole seed grinded & $0,50 \%, 100 \%$ & 10 days & FA profile & Komprda et al., 2013 \\
\hline
\end{tabular}

FA, fatty acid. 
seed inclusion had a slightly lower performance. The fishy flavour associated with linseed dietary inclusion has been frequently reported (Caston et al., 1994) this work however shows that FA composition can be improved by mixing chia seeds with a low dose of linseed $(<5 \%)$ (and thus reducing any side effects associated with linseed) this way organoleptic quality and productivity are not affected while nutraceutical quality is improved. Antruejo et al. (2011) compared the dietary effect of chia (oil and seed) and flaxseed (oil and seed) on egg quality. Chia oil and chia seed outperformed flaxseed yielding 54.5 and $63.5 \%$ more $\mathrm{mg}$ of $\omega-3$ fatty acid per $g$ of yolk during a test period of the 56 days, and 13.4 and $66.2 \%$ more for the $84 \mathrm{~d}$ test period, than flaxseed oil and flaxseed, respectively. Finally in the work of Coorey et al. (2015) chia floor was compared flaxseed and marine oils. A diet containing 30 and $40 \%$ of chia floor was more effective in increasing ALA content compared to flaxseed oil or marine oil, the best results in terms of quality were obtained at 30\% (highest eggs ALA content) while at $40 \%$ inclusion eggs colour obtained the lowest score at panel test analysis. However LC-omega-3 eicosapentaenoic (EPA) and DHA were only found in eggs from hens fed with marine oil. Chia has also been tested on quails eggs quality (Komprda et al., 2013) at three inclusion rates $(0,5.5 \%$ and $7.5 \% \mathrm{w} / \mathrm{w})$. One of the novelties in this study is that the dietary effect of chia was also quantified in terms short-chain to long-chain omega-3 bioconversion efficiency. In agreement with findings on hen eggs ALA content increased with increasing chia content, from $125 \mathrm{mg} / 100 \mathrm{~g}$ of control group to 284 and $395 \mathrm{mg} / 100 \mathrm{~g}$ for chia diets. Part of this ALA was converted into long-chain omega-3. LC-omega-3 EPA+DHA increased from $85 \mathrm{mg} / 100 \mathrm{~g}$ of control to the 96 and 106-mg/100 g of the $5.5 \%$ and the $7.5 \%$ chia diets respectively. PUFAn6/PUFAn-3 ratio in quails egg decreased linearly with increasing dietary ALA content $(p<0.05)$. Several studies addressed the effects of chia on poultry meat quality and productive performances, in agreement with the results obtained on laying hens chia inclusion in a few cases slightly affected animals growth rate, no toxic effects were reported and all studies converge on the positive effects on meat FA profile. Ayerza et al. (2002) compared the effects on broiler meat quality of two chia-enriched diets $(10 \%$ and $20 \%$ chia seed inclusion) to a control diet for 7 weeks. By the fourth week of supplementation feed conversion ratio was significantly higher in chia groups (1.96 vs 2.12 for control and chia at $20 \%$ ), overall chia diet reduced body weight up to $6.2 \%$ (at $20 \%$ chia inclusion). According to the authors however this reduction is well below the $17.3 \%$ reduction reported by in literature for broilers fed with $15 \%$ flaxseed whole seeds and was not accompanied to any symptoms of toxicity. Since intact seeds were found in chicken manure, these authors hypothesized that the mucilage produced by hydrated seeds can constitute a physical barrier hindering fat extraction. Chia diet dramatically improved meat FA profile: significantly lowered the saturated fatty acid content as well as the both the ratio between saturated and polyunsaturated fatty acid and the omega- 6 to omega- 3 ratio of white and dark meat. ALA incorporation rate differed between meat types, deposition reached $8.85 \%$ and $5.72 \%$ respectively in white and dark meat with the $20 \%$ chia inclusion. No significant difference was found between chia diets therefore one of the highlights of this study is that the $20 \%$ dose needs to be further increased to yield a significantly higher ALA concentration compared to the $10 \%$ diets. As mentioned at $20 \%$ inclusion body weight was reduced, if the hypothesis regarding the role of mucilage in reducing fat absorption is ascertained this negative effect could be overcome through seed processing (e.g. thermal treatments or oil extraction). Another study showed that chia low inclusion levels 5\% and 10\% (Salazar-
Vega et al., 2009) did not reduce body weight and on the opposite improved feed conversion ratio. The study shows that even a $10 \%$ inclusion was sufficient to improve meat FA profile, in agreement with Ayerza et al. (2002) palmitic acid decreased and ALA increased significantly. Azcona et al. (2008) compared the effects of several diets (rapeseed, flaxseed, chia seed and chia meal) and found that two chia diets including ground seed or either chia meal (at $15 \%$ inclusion) increased meat ALA content. Chia seed gave the highest ALA increase (by $157 \%$ and $200 \%$ increases for dark and white meat respectively). All seeds except rapeseed increased tissues ALA, LC-omega 3 and total PUFA however the highest PUFA content was obtained supplying chia seeds. Flaxseed negatively affected productive performances by reducing body weights, weight gain and feed conversion ratios as compared to other feeds. Overall all of the omega-3 rich diets significantly reduced saturated fatty acids and omega-6:omega-3 ratio, but the study proves that these oilseeds are not biologically equivalent. Komprda et al. (2013) found that $6 \%$ of ground chia seed increased ALA content in broilers meat increased from 15 and 30 (mg/100 g fresh weight) of control (breast and thigh respectively) to 239 and 237 (mg/100 $\mathrm{g}$ fresh weight) measured in the two tissues compared to the chia group. Part of this ALA was converted into long-chain omega- 3 in a proportion that was a function of the dietary ALA content. Namely increasing dietary ALA content resulted in a lower bioconversion efficiency: when a dietary ALA accounted for $50 \mathrm{mg} / 100 \mathrm{~g}$ feed almost $6 \%$ was converted into DHA incorporated in edible tissues, while at a $1340 \mathrm{mg} / 100 \mathrm{~g}$ this percentage decreased to $0.4 \%$. Regarding docosapentaenoic acid (DPA) and EPA the authors showed that an increase of $1 \mathrm{mg}$ dietary ALA for $100 \mathrm{~g}$ correspond to $0.36 \mathrm{mg}$ of EPA and $0.17 \mathrm{mg}$ of DPA deposited in broiler meat. They concluded that in order to enrich chicken meat with longchain omega-3 the optimal chia inclusion level is $60 \mathrm{~g} \mathrm{~kg}^{-1}$. Overall all studies published in poultry science show that dietary chia can greatly improve the FA profile of meat an eggs increasing their nutraceutical value and possibly their marketability. A slight reduction of productive performances at high chia doses was attributed to chia seed fibre content indicating that a $20 \%$ inclusion can be considered an upper limit at least for certain strains. The comparison with linseed diets showed that chia is a sound alternative or a complementary omega-3 source. Based on these data chia can be considered a safe ingredient capable of improving poultry products quality even when very small amounts $(6 \% \mathrm{w} / \mathrm{w})$ are added to the diet.

\section{Chia use in rabbit nutrition}

The majority of research work on chia potential in animal nutrition has been developed in poultry science, encouraging results though have been obtained on rabbits for which chia has been tested in various forms, supplements include: pelleted seeds, chia oil and discarded seeds (Table 6). While the wide range of feed sources hamper the comparison between experiments, these studies open ground on the use of chia co-products (oil) and byproducts (discarded seeds) in rabbit nutrition to improve both products quality and animal health status. Dietary use of whole chia seeds in rabbit nutrition were first studied by Meineri and Peiretti (2007) with the purpose of assessing chia effects on feed digestibility. Three isocaloric, isonitrogenous diets were compared containing $0,10 \%$ and $15 \%(\mathrm{w} / \mathrm{w})$ chia whole seeds respectively, all diets pelleted fresh. The control diet was a standard formula containing soybean oil and palm oil, chia totally replaced palm oil $(4 \%)$ and partially replaced soybean oil (12\% in control and $11 \%$ and $10 \%$ in low and high dose chia diets). The study demonstrated that up to $150 \mathrm{~g} / \mathrm{kg}$ feed of chia seeds can be safely added to rabbit 
diet leading to an increased digestibility of dry matter, organic matter and gross energy compared control diet. While digestibility of crude protein, crude fibres and neutral detergent fibre did not differ from control, at the $15 \%$ chia dose acid detergent fibre digestibility did not differ from control but was significantly lower than the values measured for the $10 \%$ diet. Another study (Peiretti and Meineri, 2008) more extensively investigated the effect of these three chia-enriched diets on growth performances, carcass traits and meat nutritional quality. Up to $15 \%$ chia inclusion did not impair growth performances and did not alter carcass characteristics (i.e. carcass yield, commercial carcass weight). Rabbits final live weight, daily and total weight gain as well as total feed consumption and feed conversion efficiency did not differ from control diet. Chia most important effect however was exerted on meat FA profile that was greatly improved through a significant decrease $(p<0.05)$ of saturated fatty acids and a dramatic dose-dependent increase of PUFA content. The high ALA content in chia seeds increased omega-3 PUFA content in both longissimus dorsi muscle (by 318 and $404 \%$ at $10 \%$ and $15 \%$ inclusion levels respectively, $\mathrm{p}<0.05$ ) and in perineal fat (by 389 at $10 \%$ and $465 \%$ at $15 \%$, $\mathrm{p}<0.05$ ). A four-fold reduction of omega- 6 to omega- 3 ratio was also recorded (from 4.55 in control to as low as 1.03 at $15 \%$ for longissimus dorsi muscle and from 4.20 to less than 1.00 in perineal fat). Chia in comparison to a standard formula improved rabbit meat nutritional quality by halving the atherogenic Index in both meat (from 0.68 to 0.37 ) and adipose tissue $(0.73$ to 0.33 ). Thrombogenic Index was reduced to less than one-third (from 0.93 to 0.28 of control and $15 \%$ chia dose respectively), a similar trend was observed in perineal fat (from 0.97 to 0.22 ). Finally Meineri and co-authors (2010) studied the effects of these same chia inclusion rates $(0,10$ and $15 \%)$ on meat quality, oxidative stability and sensory traits. Chia did not impaired meat gross properties (water, protein, lipid and ash content did not change), the $\mathrm{pH}$ measured 60' after slaughtering was significantly higher in chia diets $\left(\mathrm{pH}_{\text {chia }}\right.$ $=6.72>\mathrm{pH}$ control $=6.26 ; \mathrm{p}<0.05$ ) but the difference disappeared after 24 hours. However compared to control diet cooking losses increased in chia groups. One of the most important results of this study is related to the dietary effect of chia on meat oxidation stability. At $15 \%$ chia inclusion meat showed a significantly higher $(p<0.05)$ susceptibility to lipid oxidation when refrigerated at $4^{\circ} \mathrm{C}$ (measurements taken at different dates over 2 weeks) and when frozen at $-20^{\circ} \mathrm{C}$ (measurements taken after two months). The lower meat oxidative stability indicate that probably chia seeds antioxidant are not sufficient to protect meat PUFA from oxidation and that additional antioxidant inputs such as vitamin $\mathrm{E}$ could be considered (Castellini et al., 1998). The use of chia by-products has been tested for the first time in rabbit nutrition by RodríguezAbello et al. (2016) who studied the dietary effect of discarded seeds at inclusion rates of $10 \%, 20 \%, 30 \%$ and $40 \% \mathrm{w} / \mathrm{w}$ ) in comparison with a standard formula. Discarded seeds are the residues obtained after mechanical harvesting and pre-cleaning of seeds, mainly consist of light weight seeds and floral fragments, according to these authors they can constitute up to $10-15 \%$ of the total harvest. Clearly this low-cost by-product compared to commercial seeds showed a lower protein $(12.3 \%$ vs $21.5 \%)$ and fat content (6.9\% vs $28.8 \%$ ), a higher fibre content and a lower digestibility. Despite the relatively low nutritional quality of discarded seeds the trial results were encouraging; no significant differences in the final body weight and body weight gain were observed between chia diets and control diet, nor among chia inclusion levels, on the other hand discarded seeds lowered the cost of feed ration (from $0.27 \mathrm{US} \$ / \mathrm{kg}$ of control to $0.23 \mathrm{US} \$ / \mathrm{kg}$ for chia diets). Chia proportions affected feed metabolism. Feed intake $(p<0.05)$ increased lin- early up to $20 \%$ inclusion ( $91 \mathrm{~g} / \mathrm{rabbit} /$ day) and declined at $30 \%$ and at $40 \%$ inclusion level. Energy conversion ratio was significantly higher at $20 \%$ inclusion compared to the other diets and the control. These differences can be attributed to the increasing proportion of fibres (that range from $14 \%$ in control to the $20 \%$ of $40 \%$ chia dose) and fat (between $4.1 \%$ in control and $5.6 \%$ in $40 \%$ inclusion level, with the lowest value of $3.5 \%$ found in the $20 \%$ dose). Diet economic efficiency calculated as a function of weight gain and feed cost showed significant differences between treatments $(\mathrm{p}<0.05)$ being significantly higher at $30 \%$ and $40 \%$ inclusion rates than control and $10 \%$ and $20 \%$ inclusions. Overall the study demonstrated that diet economic efficiency can be increased by adding discarded chia seeds at inclusion rates between $30 \%$ and $40 \%$ but the effect on meat quality remain to be tested. Only one work analysed the use of chia oil (at 10\% inclusion) as a functional feed for hypercholesteraemic rabbit (Sierra et al., 2015). The study showed how a hypercholesterolemic diet alters the vascular functions and how supplementing chia oil for 6 weeks was sufficient to attenuate triglycerides rise and increase plasma ALA contributing to partially restore the impaired vascular functionality.

\section{Chia use in pig nutrition}

To the best of our knowledge only one work investigated the effect of chia supplementation to finishing pigs (Coates and Ayerza, 2009), in this work chia whole seeds were included in pigs diet at inclusion rates of $0 \%, 10 \%$ and $20 \%$ for 63 days As found for other species chia enrichment had no adverse effect on animal health and growth performance and positively affected meat FA profile. These positive effects however were large and significant on subcutaneous adipose tissue while no significant changes were detected on perineal fat deposits. Both $10 \%$ and $20 \%$ chia inclusion levels reduced meat fat palmitic acid content as well as total saturated FA (up to 23\%) without significant differences between chia diets. Linoleic acid increased considerably in chia groups, a five-fold increase was observed without significant differences between diets. Meat fat ALA content at $20 \%$ chia inclusion increased as much as by $333 \%$. Sensory analysis revealed consumers preference for chia enriched meat: aroma and flavour scored significantly higher for the $10 \%$ group, no adverse effects were associated to $20 \%$ inclusion however. The positive or not negative score attributed to chia enriched products, in line with data on other species, is one of the point of strength of chia seed use in animal nutrition since the off-flavours associated to other popular omega-3 rich oilseeds such as linseed, falseflax or to fishoils frequently reduce consumers acceptability.

\section{Chia use in ruminants nutrition}

There is a great interest in dairy industry in improving the FA profile of milk and cheese by increasing PUFA context, as it is well recognised that saturated FA are commonly associated to an increased risk of cardiovascular system failure (Hu et al., 1999). Despite this interest and the relative wide diffusion of chia for rabbits and broilers diets, limited research has been conducted on dairy animals. To the best of our knowledge only one work tested the effects of chia inclusion in lactating cows (Ayerza and Coates, 2006) and very recently chia has been tested on lactating goats (Martinez, 2013; Schettino et al., 2017). In Holstein cows a 17\% chia inclusion has been evaluated as a partial replacement of concentrate and oilseeds (replacement on dry matter basis) was tested as an alternative to soybean meal (10\% in control diet) and as a partial replacement of maize and wheat flour (Ayerza and Coates, 2006). The resulting chia diet had lower protein content (14\% vs 
$18 \%$ of control) and twice as much as the fat content of the control diet. Despite these differences milk yield was not significantly lowered in chia group, and no significant differences were found in cholesterol content and total fat. Chia diet contained as much as 82 times the ALA of the control, however ALA content in milk only increased by $20 \%$, possibly due to rumen bio-hydrogenation. Schettino et al. (2017) tested the effect of three inclusion levels of chia $(0,2.7 \%$ and $5.5 \%)$ in the diet of Saneen goats during the last third of the lactation period, animals belonging to the control group were fed with a iso-energetic, iso-nitrogenous control diet (160 g of crude protein/d and $11 \mathrm{MJ}$ of metabolisable energy/d), based on barley hay and corn silage supplemented with concentrate (corn and soybean meal). Chia diets did not alter milk yield and gross properties compared to control diet, therefore in agreement with the data on dairy cows, no adverse effect on productivity was observed, digestibility was unaffected. The lower chia dose $(2.7 \%)$ was not sufficient to produce sizable effects on animal performances or products quality while the $5.5 \%$ dose, compared to control diet, resulted in a higher feed intake (>nitrogen, $>\mathrm{DM},>\mathrm{OM}$ ) and significantly improved milk FA profile. Total saturated fatty acids were reduced by $3.4 \%$, mainly through the decrease of medium chain FA, while short chain FA did not change. The higher chia inclusion level corresponded to a higher milk MUFA content $(+19 \%, p<0.05)$, this was mainly related to the higher content of C18:0 and C18:1n-9 cis resulting from the rumen biohydrogenation of both ALA and linoleic acid, whose content in milk did not differ from control. With the highest chia dose PUFA content increased by as much as $20 \%$, both inclusion levels were capable of increasing conjugated linolenic acid (CLA) isomers. Specifically total CLA content increased from 0.33 to $0.73 \%$ with chia diet. Overall the high dose of chia decreased the atherogenicity index by as much as $25 \%$. Martinez et al. (2013) supplemented dairy goats with $700 \mathrm{~g}$ discarded chia seeds (52\% purity, equivalent to 360 grams of chia seeds per goat per day) and compared this diet with a $400 \mathrm{~g}$ supplementation of corn concentrate, despite the perspective imbalance between diets (due to the iso-dry matter replacement) productivity was not affected. Consistent with other trials milk nutraceutical quality was greatly improved: atherogenicity index that decreased by $36 \%$, short chain SFA did not change but $\mathrm{C} 12: 0, \mathrm{C} 14: 0$ and $\mathrm{C} 16: 0$ decreased significantly $(p<0.05)$ by $26 \%, 26 \%$ and $22 \%$, respectively. Vaccenic acid increased by $133 \%$ together with CLA 9cis; 11 trans isomer (+97\%), ALA and linoleic acid increased by $45 \%$ and $61 \%$ respectively, these relatively modest increase are attributable to rumen bio-hydrogenation, as also suggested by the relatively high content of C18:0 (13.56\% vs 9.94\% in chia and control diet respectively). Chia dietary inclusion was also tested in lamb fattening (Table 6), in agreement with results obtained for other species chia dietary addition did not impair animal growth and improved meat FA profile. Mendizabal and co-authors (2011) tested the effects of oilseeds (chia and linseed) on lambs growth and carcass quality. A $10 \%$ chia seed inclusion and a $10 \%$ linseed supplementation were compared with a standard soybean-based commercial formula. Both chia and linseed did not alter Andorra lambs growth rate and carcass quality compared to control diet, sensory analysis revealed that animals fed with chia had a slight change in fat colour (yellow shade) while in linseed group fat colour was described as white and luminous. Interestingly however another study showed that at $10 \%$ levels of inclusion both chia and linseed greatly improved lamb meat fatty acid profile compared with a standard soybean-based control (Insausti et al., 2011). No significant differences were found between chia and linseed-fed animals. Both chia and linseed significantly $(\mathrm{p}<0.05)$ increased meat ALA content $(\mathrm{g} / 100 \mathrm{~g}$ total
FA) rising it from the 0.52 of the control group to the 1.84 and 1.73 of linseed and chia-fed lambs respectively. Long-chain omega-3 EPA and DHA (g/100 g total FA) also increased slightly compared to control diet $(0.21 \mathrm{EPA}$ control diet $<0.42 \mathrm{EPA}$ linseed $=0.36 \mathrm{EPA}$ chia, $\mathrm{p}<0.05$; and 0.46 DHA control diet $<0.6$ linseed $=0.54$ chia, $\mathrm{p}<0.05)$. DHA did not change. This omega-3 enrichment positively affected omega-6/omega-3 ratio that was nearly halved (4.56 of linseed $=4.88$ of chia, $p>0.05$ ) compared to the control (9.5). While chia and linseed inclusion were equally important in improving FA profile the sensory analysis revealed consumers preference for the meat produced with animals fed with chia diet $(\mathrm{p}<0.05)$ a result consistent with those obtained by Ayerza and Coates (2009) when chia was tested in finishing pig. Differences in Navarra lamb FA profile induced by flaxseed (raw and extruded) and raw chia seeds were investigated by Urrutia et al. (2015) who tested a partial concentrate replacement with either $10 \%(\mathrm{w} / \mathrm{w})$ chia raw seed or a $10.5 \%(\mathrm{w} / \mathrm{w})$ linseed formula (containing 70\% extruded linseed and $30 \%$ wheat bran). In agreement with other studies both chia and linseed partial replacement had no adverse effect on productive performances and improved meat FA profile, namely both chia and linseed supplementation increased ALA, eicosapentaenoic acid (EPA, C20:5n-3) in of the intramuscular and subcutaneous adipose tissue $(\mathrm{p}<0.001)$, the $n-6 / n-3$ decreased from the 6.26 of control group to the 3.12 and 3.87 of linseed and chia respectively $(p<0.001)$. Linseed increased DPA in both adipose tissues while chia increased DPA only at intramuscular level. These authors also found differences between linseed and chia on the expression of several genes involved in lipogenesis that could contribute to explain why chia and linseed omega-3 enrichment was tissue-specific. Chia seeds ALA content was higher than that of linseed (47.5\% vs $33.7 \%$ respectively), nevertheless the concentration in meat was similar, suggesting that chia ALA possibly underwent through a higher rate of rumen bio-hydrogenation. Overall this first results on ruminant point to a relatively low Chia-ALA incorporation rate due to rumen bio-hydrogenation, therefore seed protecting technologies/antioxidant enrichment should be considered. Overall the results on ruminants indicate that Chia even at low doses $(10 \%)$ can improve the quality of products without adverse effects on growth parameters.

\section{Chia feed in aquaculture}

Recently chia supplementation has been introduced in aquaculture. Dietary chia effects have been tested on freshwater fish Nile tilapia (Oreochromis niloticus) (Table 6). Silva et al. (2014) used for the first time chia in aquaculture. Specifically chia bran at 5\% inclusion was tested as an alternative to soybean oil. After 45 days of chia supplementation, ALA incorporation increased by $876 \%$ compared to the $104 \%$ increase under control diet. Fillet EPA and DHA increased from 1.12 to $1.56\left(\mathrm{mg} 100 \mathrm{~g}^{-1}\right)$, and from 19.55 to $26.55\left(\mathrm{mg} 100 \mathrm{~g}^{-1}\right)$ respectively. Chia supply decreased saturated fatty acid (SFA), increased PUFA/SFA ratio (from 0.79 to 1 in chia diet) and a reduced omega-6/omega-3 ratio (from 12.07 to 3.77 ). In another study (Carbonera et al., 2016) chia oil has been evaluated as a lipid source, comparing a control diet in which the lipid fraction was provided by sunflower oil (1.90\% inclusion) and chiaenriched diet in which sunflower was replaced by a blend of $0.63 \%$ chia oil, $0.63 \%$ tung oil, and $0.63 \%$ synthetic supplement of conjugated linoleic acid, the chia diet was also supplemented with $0.015 \%$ vitamin E. Clearly diet formulation (blend of different lipid sources supplemented with antioxidant) does not allow to discern the effect of chia alone on FA and antioxidant profile, except for ALA incorporation (since chia was the only source), as found for other species chia addition increased 2.9 times ALA content 
(from $6.56 \mathrm{mg} \mathrm{g}^{-1}$ at the beginning of the experiment to $19.03 \mathrm{mg}$ $\mathrm{g}^{-1}$ after 60-day of supplementation). Omega-6/omega-3 ratio decreased from 25.25 of control diet to 4.89 of supplemented diet. Chia has not yet been compared with other omega-3 sources such as linseed. Finally Montanher et al. (2016) compared a commercial formula with 3 enriched diets containing: chia oil (1.90\%) alone, avocado peel extract $(0.14 \%)$ and a blend between these two ingredients in tilapias diet. In this trial chia oil totally replaced soybean oil. Chia diet gave the best results in terms weight gain [from $15 \mathrm{~g}$ at the beginning of the trial to $49.51 \mathrm{~g}$ at the end of the trial (45 days)] while the animals supplemented with avocado or avocado + chia reached a slightly lower final weight (42.55 and 43.21 respectively). ALA increased from $204.80 \mathrm{mg} \mathrm{g}^{-1}$ of control diet to the $1165.79 \mathrm{mg} \mathrm{g}^{-1}$ of the chia+avocado blend diet while linoleic acid diminished from 2407.63 to $1937.33 \mathrm{mg} \mathrm{g}^{-1}$. These changes led to a considerable reduction of the omega-6/omega-3 ratio from 12.27 of control to 1.70 of chia oil diet. EPA and DHA increased with chia diet (EPA was around $0.8 \mathrm{mg}$ g TFA and DHA around $14 \mathrm{mg}$ g TFA). Interestingly fish treated with chia oil showed a large increase in antioxidant capacity in the lipophilic fraction, while no significant differences in the hydrophilic fractions were found between diets. Besides PUFA therefore the chia diet increased the content of lipophilic antioxidants (e.g. tocopherol), which (unlike hydrophilic antioxidant that were excreted) were incorporated into cellular membranes and became bioavailable in food.

\section{Chia use in edible insects nutrition}

Dietary chia effects was tested on two species with an established use in human diet: cricket (Gryllus assimillis) and giant mealworm (Zophobas atratus) at the last nymphal stadium and at the last larval stadium respectively (Komprda et al., 2013). In both cases feeding on chia as an alternative to wheat bran increased dramatically ALA content. In cricket ALA increased from 12 to 3229 $\mathrm{mg} / 100 \mathrm{~g}$ fresh weight at $50 \%$ inclusion and up to $3460 \mathrm{mg} / 100 \mathrm{~g}$ fresh weight for $100 \%$ diet, while in giant mealworm there was a relatively modest shift from 33 to 702 and $1520 \mathrm{mg} / 100 \mathrm{~g}$ fresh weight at $50 \%$ and $100 \%$ inclusion respectively. Only cricket was able to synthetise long-chain omega-3 EPA. EPA increased in cricket up to $16 \mathrm{mg} / 100 \mathrm{~g}$ fresh weight similarly under both chia doses. The study proves that dietary consumption of chia-fed crickets can contribute to increase EPA intake in humans although a $100 \mathrm{~g}$ serving (corresponding to $20 \mathrm{mg}$ of EPA) would only satisfy about $5 \%$ of recommended daily intake.

\section{Chia whole plant as a forage source}

As mentioned above there are no published work on the use of chia herbage in animal nutrition, however forage use of chia vegetative parts was suggested by Peiretti and Gai (2009), who determined a whole panel of chemical analyses relevant for animal nutrition. According to these authors chia plant biomass is a good source of polyunsaturated fatty acids (with ALA proportion varying between 649 and $565 \mathrm{~g} / \mathrm{kg}$ total FA between early and late vegetative stage). The stage before shooting is the best time for harvesting forage with a good nutritive value. The protein content in fact varies between 188 (g/kg DM basis) at early vegetative stage and $122(\mathrm{~g} / \mathrm{kg} \mathrm{DM})$ at late vegetative stage to fall at $76(\mathrm{~g} / \mathrm{kg} \mathrm{DM})$ during shooting stage. Besides results on fatty acids and protein reported above, they found that forage quality of chia vegetative plants changes with growth stage from early vegetative stage to plant budding with an increase in fibrous fractions (acid and neu- tral detergent fibre and lignin) and gross energy and a decrease in fats and ashes. Another study (Peiretti, 2010) suggested that chia whole plant harvested at the budding stage has a good potential for large scale ensiling. Biomass values presented in section 2 show that whole plants can be grown successfully at all latitudes with high values even in Europe with short-day genotypes. Parameters related to ensilability were determined by Peiretti (2010) who found a decrease in buffering capacity and an increase in water soluble carbohydrates from 86 to $213 \mathrm{~g} / \mathrm{kg}$ of dry matter (DM), and significant variations in $\mathrm{pH}$ and soluble nitrogen with proceeding plant growth stage. In a lab-scale facility the author ensiled plants harvested at budding with four different methods (cut silage and wilted silages at three levels of wilting). Results indicate that some alcohols and volatile fatty acids (but no lactic acid) are produced during fermentation and only isobutyric acid decreased with increasing wilting level. He concluded that chia vegetative parts could be considered for ensiling if collected at the budding stage and wilted to more than $285 \mathrm{~g} / \mathrm{kg}$ of dry matter. Bilalis et al. (2016) conducted an agronomic trial and found that fertilising with manure affects crude protein and both acid and neutral-detergent fibre. The high nutritional quality of chia herbage at early vegetative stages suggests another potential use of chia in animal nutrition in the form of sprouts. Dal Bosco and co-authors (2015) showed that alfalfa and linseed sprouts supplemented to rabbits improved meat fatty acid profile by increasing PUFA and decreasing omega-6:omega-3 ratio and the throbogenic index.

\section{Further prospects}

Up to now research on chia in the livestock sector only addressed the dietary effects on products quality, but another potential use might be related to antimicrobial properties of chia extracts. Using ethanol extracts of seeds and green parts of chia Patil et al. (2014) showed the effect on paralysys and death of earthworms as a model for intestinal parasitic worms. Essential oils from chia leaves include $\beta$-caryophyllene, globulol, $\gamma$-murolene, $\beta$-pinene, $\alpha$-humulene, germacrene-B, and widdrol (Ahmed et al., 1994; Elshafie et al., 2018). Ahmed et al. (1994) suggests that chia leaf oils could be used as insect repellent. Elshafie et al. (2018) tested essential oils on several fungi and bacteria; antifungal effect was important especially against Aspergillus. fumigatus, Penicillium. expansum, Monilia laxa, and M. fructigena; the antibacterial action of chia essential oils was strong against a number of Gram + bacteria. The antimicrobial activity of extracted essential oils shown by Elshafie et al. (2018) may be useful against bacterial and fungal contamination of forages. These effects coupled with a possible insect repellent capacity suggest that chia extracts may play a role in the prevention and treatment of parasitic burden.

\section{Conclusions}

The current body of knowledge on use in animal nutrition indicate that chia seeds can be considered an omega- 3 boosting feed ingredient. Sizeable improvement of animal products fatty acid profile can be obtained even at low doses $(6 \% \mathrm{w} / \mathrm{w})$. If raw seeds are used, high inclusion rates $(>20 \%)$ can slightly reduce productive performances, an effect possibly linked mucilage contained in the seeds which can act as a physical barrier hindering nutrients 
absorption at least in some species/breeds. The use of by-products such as discarded seeds can be a successful way to improve products omega-3 content at a very low cost. Studies on ruminants indicate that chia lipids undergo a substantial rumen bio-hydrogenation, and also a low oxidative stability of meat produced by rabbit fed with chia was reported, indicating that seed antioxidants might not be sufficient to protect PUFA and that the addition of antioxidants supplements could help increase omega-3 incorporation rate. One of the points of strength of dietary chia is the total lack of antinutritional compounds coupled with the absence of undesirable off-flavours in the final products. Chia in livestock is essentially used as an omega-3 boosting feed. ALA proportion in seeds is relatively high $(>60 \%)$ with genotype and environmental factors playing a major effect on the fatty acid composition rather than the total oil content. Seed yield of commercial short-day flowering varieties can be as high as $3 \mathrm{~T} \mathrm{ha}^{-1}$ in the countries of origin but is severely reduced at northern latitudes where the reduction of day length is accompanied by a decrease of air temperature that can compromise seed ripening process. Data on seed yield in Europe indicate that seed production would only be viable if genotypes with reduced photoperiod sensitivity will be released. Whole plant biomass and leaf biomass, on the opposite, can be remarkably high at European latitudes even with short-day flowering commercial varieties. Chia vegetative tissues display an ALA content between 649 and $565 \mathrm{~g} / \mathrm{kg}$ total FA between early and late vegetative stage and are also a source of protein and secondary metabolites. The forage use of chia remains to be tested but data on forage quality and ensilability are encouraging. If whole-plant use in livestock sector will be validated, novel cropping opportunities will emerge for this crop in European crop-livestock systems even using commercially available short-day flowering varieties.

\section{References}

Abete I, Romaguera D, Vieira AR, Lopez De Munain A, Norat T, 2014. Association between total, processed, red and white meat consumption and all-cause, CVD and IHD mortality: a meta-analysis of cohort studies. Br. J. Nutr. 112:762-75.

Ahmed M, Ting IP, Scora RW, 1994. Leaf oil composition of Salvia hispanica L. from three geographical areas. J. Essent Oil Res. 6:223-8.

Alenbrant R, Benetoli da Silva T, Soares de Vasconcelos A, Mourão W, Corte e J, 2014. O cultivo da Chia no Brasil: futuro e perspectivas. J. Agric. Sci. Umuarama 3:161-79.

Alonso-Calderón A, Chávez-Bravo E, Rivera A, Montalvo-Paquini C, Arroyo-Tapia R, Monterrosas-Santamaria M, JiménezSalgado T, Tapia-Hernández A, 2013. Characterisation of black chia seed (Salvia hispanica L) and oil and quantification of $\beta$-sitosterol. Int. J. Biol. Sci. 2:70-2.

Amato M, Caruso MC, Guzzo F, Galgano F, Commisso M, Bochicchio R, Labella R, Favati F, 2015. Nutritional quality of seeds and leaf metabolites of Chia (Salvia hispanica L.) from Southern Italy. Eur. Food Res. Techno. 241:615-25.

Antruejo A, Azcona JO, Garcia PT, Gallinger C, Rosmini M, Ayerza R, Coates W, Perez CD, 2011. Omega-3 enriched egg production: the effect of $\alpha$-linolenic $\omega-3$ fatty acid sources on laying hen performance and yolk lipid content and fatty acid composition. Br. Poult. Sci. 52:750-60.

Ayerza R, 1995. Oil content and fatty acid composition of chia (Salvia hispanica L.) from five northwestern locations in Argentina. J. Am. Oil Chem. Soc. 72:1079-81.
Ayerza R, 2010. Effects of seed color and growing locations on fatty acid content and composition of two Chia (Salvia hispanica L.) genotypes. J. Am. Oil Chem. Soc. 87:1161-5.

Ayerza R, 2011. The seed's oil content and fatty acid composition of chia (Salvia hispanica L.) variety Iztac 1, grown under six tropical ecosystems conditions. Interciencia 8:620-4.

Ayerza R, 2013. Seed composition of two chia (Salvia hispanica L.) genotypes which differ in seed color. Emir. J. Food Agric. 25:495-500.

Ayerza R, Coates W, 1999. An $\omega-3$ fatty acid enriched chia diet: influence on egg fatty acid composition, cholesterol and oil content. Can. J. Anim. Sci. 79:53-8.

Ayerza R, Coates W, 2000. Dietary levels of chia: influence on yolk cholesterol, lipid content and fatty acid composition for two strains of hens. Poult. Sci. 130:724-39.

Ayerza R, Coates W, 2001. Omega-3 enriched eggs: the influence of dietary a-linolenic fatty acid source on egg production and composition. Can. J. Anim. Sci. 81:355-62.

Ayerza R, Coates W, 2002. Dietary levels of chia: influence on hen weight, egg production and sensory quality, for two strains of hens. Br. Poult. Sci. 43:283-90.

Ayerza R, Coates W, 2004. Protein and oil content, peroxide index and fatty acid composition of chia (Salvia hispanica L.) grown in six tropical and subtropical ecosystems of South America. Trop. Sci. 44:131-5.

Ayerza R, Coates W, 2005. Chia: rediscovering a forgotten crop of the Aztecs. University of Arizona Tucson, AZ, USA. Available from: http://www.uky.edu/Ag/CDBREC/introsheets/chia.pdf

Ayerza R, Coates W, 2006. Influence of chia on total fat, cholesterol, and fatty acid profile of Holstein cow's milk, 2006. Rev. Cient. UCES 2:39-48

Ayerza R, Coates W, 2007. Seed yield, oil content and fatty acid composition of three botanical sources of $\omega-3$ fatty acid planted in the Yungas ecosystem of tropical Argentina. Trop. Sci. 47:183-7.

Ayerza R, Coates W, 2009. Influence of environment on growing period and yield, protein, oil and a-linolenic content of three chia (Salvia hispanica L.) selections. Ind. Crops Prod. 30:321-4.

Ayerza R, Coates W, 2011. Protein content, oil content and fatty acid profiles as potential criteria to determine the origin of commercially grown chia (Salvia hispanica L.). Ind. Crop. Prod. 34:1366-71.

Ayerza R, Coates W, Lauria M, 2002. Chia seed (Salvia hispanica L.) as an omega-3 fatty acid source for broilers: influence on fatty acid composition, cholesterol and fat content of white and dark meats, growth performance, and sensory characteristics. Poult. Sci. 81:826-37.

Azcona JO, Schang MJ, Garcia PT, Gallinger C, Ayerza Jr R, Coates W, 2008. Omega-3 enriched broiler meat: The influence of dietary $\alpha$-linolenic- $\omega-3$ fatty acid sources on growth, performance and meat fatty acid composition. Can. J. Anim. Sci. 88:257-69.

Baginsky C, Arenas J, Escobar H, Garrido M, Valero N, Tello D, Pizarro L, Valenzuela A, Morales L, Silva H, 2016. Growth and yield of chia (Salvia hispanica L.) in the Mediterranean and desert climates of Chile. Chilean J. Agric. Res. 76:255-64.

Beltrán-Orozco MC, Romero MR, 2003. La chía, alimento milenario. Departamento de Graduados e Investigación en Alimentos. E. N. C. B., I. P. N., Mexico.

Berger ME, Smesny S, Kim SW, Davey CG, Rice S, Sarnyai Z, Schlögelhofer M, Schäfer MR, Berk M, McGorry PD, Amminger GP, 2017. Omega-6 to omega-3 polyunsaturated fatty acid ratio and subsequent mood disorders in young people 
with at-risk mental states: a 7-year longitudinal study. Transl. Psychiat. 7:e1220.

Bernardini M, Dal Bosco A, Castellini C, 1999. Effect of dietary n$3 / \mathrm{n}-6$ ratio on fatty acid composition of liver, meat and perirenal fat in rabbits. Anim. Sci. 68:647-54.

Bilalis D, Tabaxi I, Zervas G, Tsiplakou E, Travlos IS, Kakabouki I, Tsioros S, 2016. Chia (Salvia hispanica) fodder yield and quality as affected by sowing rates and organic fertilization. Commun. Soil Sci. Plant. Anal. 47:1764-70.

Bochicchio R, Philips TD, Lovelli S, Labella R, Galgano F, Marisco AD, Perniola M, Amato M 2015a. Innovative crop productions for healthy food: The case of Chia (Salvia hispanica L.). In: Vastola A. (ed.) The sustainability of agro-food and natural resource systems in the Mediterranean Basin. Springer International Publishing, Berlin, Germany, pp. 29-45.

Bochicchio R, Rossi R, Labella R, Bitella B, Perniola M, Amato M, 2015b. Effect of sowing density and nitrogen top-dress fertilisation on growth and yield of Chia (Salvia hispanica L.) in a Mediterranean environment: first results. Ital. J. Agron. 10:163-6.

Bushway A, Wilson A, Houston L, Bushway R, 1984. Selected properties of the lipid and protein fractions from chia seed. J. Food Sci. 49:555-7.

Bushway AA, Belya PR, Bushway RJ, 1981. Chia seed as a source of oil, polysaccharide, and protein. J. Food Sci. 46:1349-56.

Cahill JP, 2003. Ethnobotany of chia, Salvia hispanica L. (Lamiaceae). Econ. Bot. 57:604-18.

Cahill JP, 2004. Genetic diversity among varieties of Chia (Salvia hispanica L.). Genet. Resour. Crop Evol. 51:773-81.

Cahill JP, Ehdaie B, 2005. Variation and heritability of seed mass in chia (Salvia hispanica L.). Genet. Resour. Crop Evol. 52:201-7.

Capitani M, Corzo-Rios L, Chel-Guerrero L, Betancur-Ancona D, Nolasco S, Tomás M, 2015. Rheological properties of aqueous dispersions of chia (Salvia hispanica L.) mucilage. J. Food Eng. 149:70-7.

Capitani MI, Nolasco SM, Toma's MC, 2013. Effect of mucilage extraction on the functional properties of Chia meals. In: Muzzalupo I. (Ed.), Food Industry. IntechOpen, pp 421-437. Available from: https://www.intechopen.com/books/foodindustry/effect-of-mucilage-extraction-on-the-functionalproperties-of-chia-meals

Capitani MI, Spotorno V, Nolasco SM, Tomás MC, 2012. Physicochemical and functional characterisation of by- products from chia (Salvia hispanica L.) seeds of Argentina. LWT Food Sci. Technol. 45:94-102.

Carbonera F, Montanher PF, Figueiredo IL, Bonafé EG, Júnior OOS, Sargi SC, Gonçalves RM, Matsushita M, Visentainer JV, 2016. Lipid composition and antioxidant capacity evaluation in tilapia fillets supplemented with a blend of oils and vitamin E. J. Am. Oil Chem. Soc. 93:1255-64.

Castellini C, Dal Bosco A, Bernardini M, Cyril HW, 1998. Effect of dietary vitamin $\mathrm{E}$ on the oxidative stability of raw and cooked rabbit meat. Meat Sci. 50:153-61.

Caston LJ, Squires EJ, Leeson S, 1994. Hen performance, egg quality, and the sensory evaluation of eggs from SCWL hens fed dietary flax. Can. J. Anim. Sci. 74:347-53.

Cherian G, Sim JS, 1991. Effect of feeding full fat flax and canola seeds to laying hens on the fatty acid composition of eggs, embryos, and newly hatched chicks. Poult Sci. 70:917-22.

Cherry JH, Bishop L, Hasegawa PM, Leffler HR, 1985. Differences in the fatty acids composition of soybean seed produced in northern and southern areas of the USA.
Phytochemistry 24:237-41.

Chilliard Y, Ferlay A, Doreau M, 2001. Effect of different types of forages, animal fat or marine oils in cow's diet on milk fat secretion and composition, especially conjugated linoleic acid (CLA) and polyunsaturated fatty acids. Livest Prod Sci. 70:31-48.

Ciftci ON, Przybylski R, Rudzińska M, 2012. Lipid components of flax, perilla, and chia seeds. Eur. J. Lipid Sci. Technol. 114:794-800.

Coates W, Ayerza R, 1996. Production potential of Chia in northwestern Argentina. Ind. Crops Prod. 5:229-33.

Coates W, Ayerza R, 1998. Commercial production of Chia in Northwestern Argentina. J. Am. Oil Chem. Soc. 75:1417-20.

Coates W, Ayerza R, 2009. Chia (Salvia hispanica L.) seed as an n3 fatty acid source for finishing pigs: effects on fatty acid composition and fat stability of the meat and internal fat, growth performance, and meat sensory characteristics. J. Animal Sci. 87:3798-804.

Coelho MS, de las Mercedes Salas-Mellado M, 2014. Chemical characterization of chia (Salvia hispanica L.) for use in food products. J. Food Nutr. Res. 2:263-9.

Coorey R, Novinda A, Williams H, Jayasena V, 2015. Omega-3 fatty acid profile of eggs from laying hens fed diets supplemented with chia, fish oil, and flaxseed. J. Food Sci. 80:180-7.

Da Silva Marineli R, Moraes ÉA, Lenquiste SA, Godoy AT, Eberlin MN, Maróstica Jr MR, 2014. Chemical characterization and antioxidant potential of Chilean chia seeds and oil (Salvia hispanica L.). LWT Food Sci. Technol. 59:1304-10.

Dal Bosco A, Castellini C, Bianchi L, Mugnai C, 2004. Effect of dietary $\alpha$-linolenic acid and vitamin $\mathrm{E}$ on the fatty acid composition, storage stability and sensory traits of rabbit meat. Meat Sci. 66:407-13.

Dal Bosco A, Castellini C, Martino M, Mattioli S, Marconi O, Sileoni V, Falcinelli B, Castellini C, Benincasa P, 2015. The effect of dietary alfalfa and flax sprouts on rabbit meat antioxidant content, lipid oxidation and fatty acid composition. Meat. Sci. 106:31-7.

Dalle Zotte A, Szendro Z, 2011. The role of rabbit meat as functional food. Meat Sci. 88:319-31.

De Falco B, Amato M, Lanzotti V, 2017a. Chia seeds products: an overview. Phytochem. Rev. 16:745-60.

De Falco B, Fiore A, Bochicchio R, Amato M, Lanzotti V, 2018a. Metabolomic analysis by UAE-GC MS and antioxidant activity of Salvia hispanica (L.) seeds grown under different irrigation regimes. Ind. Crops Prod. 112:584-92.

De Falco B, Fiore A, Rossi R, Amato M, Lanzotti V, 2018b. Metabolomics driven analysis by UAEGC-MS and antioxidant activity of chia (Salvia hispanica L.) commercial and mutant seeds. Food Chem. 254:137-43.

De Falco B, Incerti G, Bochicchio R, Phillips TD, Amato Mm, Lanzotti V, 2017b. Metabolomic analysis of Salvia hispanica seeds using NMR spectroscopy and multivariate data analysis. Ind. Crops Prod. 99:86-96.

Dewhurst RJ, Fisher WJ, Tweed JKS, Wilkins RJ, 2003. Comparison of grass and legume silages for milk production. 1. Production responses with different levels of concentrate. J. Dairy Sci. 86:2598-611.

Dewhurst RJ, Shingfield KJ, Lee MA, Scollan ND, 2006. Increasing the concentrations of beneficial polyunsaturated fatty acids in milk produced by dairy cows in high-forage systems. Anim. Feed Sci. Technol. 131:168-206.

Di Marsico A, Scrano L, Amato M, Gàmiz B, Real M, Cox L, 2018a. Mucilage from seeds of chia (Salvia hispanica L.) used as soil conditioner; effects on the sorption-desorption of four herbicides 
in three different soils. Sci. Total Environ. 625:531-8.

Di Marsico A, Scrano L, Labella R, Lanzotti V, Rossi R, Cox L, Perniola M, Amato M, 2018b. Mucilage from fruits/seeds of chia (Salvia hispanica L.) improves soil aggregate stability. Plant Soil 425:57-69.

Dubois V, Breton S, Linder M, Fanni J, Parmentier M, 2007. Fatty acid profiles of 80 vegetable oils with regard to their nutritional potential. Eur. J. Lipid Sci. Technol. 109:710-32.

Elshafie HS, Aliberti L, Amato M, De Feo V, Camele I, 2018. Chemical composition and antimicrobial activity of chia (Salvia hispanica L.) essential oil. Eur. Food Res. Technol. 244:1675-82.

Epling CC, 1940. A revision of salvia, subgenus calosphace. Verlag des Repertoriums, Fabeckstr., Berlin, Germany, 49.

European Food Safety Authority, 2009. Scientific opinion of the Panel on Dietetic Products Nutrition and Allergies on a request from the European Commission on the safety of 'Chia seed (Salvia hispanica) and ground whole Chia seed' as a food ingredient. EFSA J. 1-2.

Felisberto M, Wahanik AL, Gomes-Ruffi C, Clerici MTPS, Chang YK, Steel CJ, 2015. Use of chia (Salvia hispanica L.) mucilage gel to reduce fat in pound cakes. LWT Food Sci. Technol. 63:1049-55.

Fraeye I, Bruneel C, Lemahieu C, Buyse J, Muylaert K, Foubert I, 2012. Dietary enrichment of eggs with omega-3 fatty acids: a review. Food Res. Int. 48:961-9.

Gonzalez-Esquerra R, Leeson S, 2001. Alternatives for enrichment of eggs and chicken meat with omega-3 fatty acids. Can. J. Anim. Sci. 81:295-305.

Heuer B, Yaniv Z, Ravina I, 2002. Effect of late salinization of chia (Salvia hispanica), stock (Matthiola tricuspidata) and evening primrose (Oenothera biennis) on their oil content and quality. Ind. Crops Prod. 15:163-7.

Hrdinka C, Zollitsch W, Knaus W, Lettner F, 1996. Effects of dietary fatty acid pattern on melting point and composition of adipose tissues and intramuscular fat of broiler carcasses. Poult. Sci. 75:208-15.

Hu FB, Stampfer MJ, Manson JE, Ascherio A, Colditz GA, Speizer FE, Hennekens CH, Willett WC, 1999. Dietary saturated fats and their food sources in relation to the risk of coronary heart disease in women. Am. J. Clin. Nutr. 70:1001-8.

Insausti K, Mendizabal JA, Sarriés MV, Zudaire G, Eguinoa P, Arana A, Beriain MJ, Purroy A, 2011. Effect of Chia (Salvia hispanica L.) supplementation on fatty acid composition and sensory characteristics of lamb meat. pp. 162-166 in XXXVI Congreso de la Sociedad Española de Ovinotecnia y Caprinotecnia (SEOC), Donostia-San Sebastián, España, 6-7 de octubre de 2011, Sociedad Española de Ovinotecnia y Caprinotecnia (SEOC).

Ixtaina VY, Martínez ML, Spotorno V, Mateo CM, Maestri DM, Diehl BWK, Nolasco SM, Tomás MC, 2011. Characterization of Chia seed oils obtained by pressing and solvent extraction. J. Food Compost. Anal. 24:166-74.

Ixtaina VY, Nolasco SM, Tomàs MC, 2008. Physical properties of Chia (Salvia hispanica L.) seeds. Ind. Crops Prod. 28:286-93.

Jamboonsri W, Phillips TD, Geneve RL, Cahill JP, Hildebrand DF, 2012. Extending the range of an ancient crop, Salvia hispanica L. - a new $\omega 3$ source. Gen. Res. Crop Evol. 59:171-8.

Jansen P, Lemmens R, Oyen L, Siemonsma J, Stavast F, van Valkenburg J, 1991. Plant resources of South-East Asia basic list of species and commodity grouping Pudoc. Wageningen, Netherlands

Kaczmarczyk MM, Miller MJ, Freund GG, 2012. The health ben- efits of dietary fibre: beyond the usual suspects of type 2 diabetes mellitus, cardiovascular disease and colon cancer. Metab. Clin. Exp. 61:1058-66.

Kolanowski W, Laufenberg G, 2006. Enrichment of food products with polyunsaturated fatty acids by fish oil addition. Eur. Food Res. Technol. 222:472-7.

Komprda T, Zorníková G, Rozíková V, Borkovcová M, Przywarová A, 2013. The effect of dietary Salvia hispanica seed on the content of n-3 long-chain polyunsaturated fatty acids in tissues of selected animal species, including edible insects. J. Food Compos. Anal. 32:36-43.

Kouba M, Benatmane F, Blochet JE, Mourot J, 2008. Effect of a linseed diet on lipid oxidation, fatty acid composition of muscle, perirenal fat, and raw and cooked rabbit meat. Meat Sci. 80:829-34.

Lattimer JM, Haub MD, 2010. Effects of dietary fibre and its components on metabolic health. Nutrients 2:1266-89.

Leskanich CO, Matthews KR, Warkup CC, Noble RC, Hazzledine M, 1997. The effect of dietary oil containing (n-3) fatty acids on the fatty acid, physicochemical, and organoleptic characteristics of pig meat and fat. J. Anim. Sci. 75:673-83.

Marineli RS, Aguiar Moraes E, Alves Leinquiste S, Teixeira Godoy A, Nogueira Eberlin M, Maróstica MR, 2014. Chemical characterization and antioxidant potential of Chilean seeds and oil (Salvia hispanica L.). LWT Food Sci. Technol. 59:1304-10.

Martinez GM, 2013. Ensayo exploratorio: obtención de leche caprina funcional a partir de la suplementación con Salvia hispanica (Chía). RIA 39:305-11.

Martínez-Cruz O, Paredes-López O, 2014. Phytochemical profile and nutraceutical potential of chia seeds (Salvia hispanica L.) by ultra-high performance liquid chromatography. J. Chromatogr. A. 1346:43-8.

Meineri G, Cornale P, Tassone S, Peiretti PG, 2010. Effects of Chia (Salvia hispanica L.) seed supplementation on rabbit meat quality, oxidative stability and sensory traits. Ital. J. Anim. Sci. 9:45-9.

Meineri G, Peiretti PG, 2007. Apparent digestibility of mixed feed with increasing levels of chia (Salvia hispanica L.) seeds in rabbit diets. Ital. J. Anim. Sci. 6:778-80.

Mendizabal JA, Eguinoa P, Díaz J, Arana A, Maeztu F, Insausti K, Sarriés MV, Soret B, Beriain MJ, Purroy A, 2011. Effect of chia (Salvia hispanica L.) supplementation on growth performances and carcass characteristics of lambs. Preliminary results. pp 634-636 in XIV Jornadas sobre Producción Animal, 17 y 18 de mayo de 2011, Zaragoza, España,

Menga V, Amato M, Phillips TD, Angelino D, Morreale F, Fares C, 2017. Gluten-free pasta incorporating chia (Salvia hispanica L.) as thickening agent: An approach to naturally improve the nutritional profile and the in vitro carbohydrate digestibility. Food Chem. 221:1954-61.

Mocking RJT, Harmsen I, Assies J, Koeter MWJ, Ruhe HG, Schene AH, 2017. Meta-analysis and meta-regression of omega-3 polyunsaturated fatty acid supplementation for major depressive disorder. Transl. Psychiat. 6:e756.

Montanher PF, Costa e Silva B, Bonafé EG, Carbonera F, dos Santos HMC, de Lima Figueiredo I, Maruyama SA, Matsushita M, Visentainer JV, 2016. Effects of diet supplementation with chia (Salvia hispanica L.) oil and natural antioxidant extract on the omega-3 content and antioxidant capacity of Nile tilapia fillets. Eur. J. Lipid Sci. Technol. 118:698-707.

Morgan CA, Noble RC, Cocchi M, McCartney R, 1992. Manipulation of the fatty-acid composition of pig meat lipids 
by dietary means. J. Sci. Food Agric. 58:357-68.

Muñoz LA, Cobos A, Diaz O, Aguilera JM, 2012. Chia seeds: microstructure, mucilage extraction and hydration. J. Food Eng. 108:216-24.

Muñoz LA, Cobos A, Diaz O, Aguilera JM, 2013. Chia seed (Salvia hispanica): an ancient grain and a new functional food. Food Rev. Int. 29:394-408.

Nestel P, Clifton P, Colquhoun D, Noakes M, Mori TA, Sullivan D, Thomas B, 2015. Indications for omega-3 long chain polyunsaturated fatty acid in the prevention and treatment of cardiovascular disease. Heart Lung Circ. 24:769-79.

Nijveldt RJ, Van Nood ELS, Van Hoorn DE, Boelens PG, Van Norren K, Van Leeuwen PA, 2001. Flavonoids: a review of probable mechanisms of action and potential applications. Am. J. Clin. Nutr. 74:418-25.

Ortiz de Montellano BR, 1978. Aztec cannibalism: an ecological necessity? Science 200:611-7.

Ouzounidou G, Skiada V, Papadopoulou KK, Stamatis N, Kavvadias V, Eleftheriadis E, Gaitis F, 2015. Effects of soil pH and arbuscular mycorrhiza (AM) inoculation on growth and chemical composition of chia (Salvia hispanica L.) leaves. Braz. J. Bot. 38:487-95.

Pan A, Chen M, Chowdhury R, Wu JHY, Sun Q, Campos H, Mozaffarian D, Hu FB, 2012. $\alpha$-Linolenic acid and risk of cardiovascular disease: a systematic review and meta-analysis. Am. J. Clin. Nutr. 96:1262-73.

Patil YA, Doijad RC, Sankpal PS, Pisal SR, Shewale RS, 2014. Investigation of in-vitro anthelmintic activity of salvia hispanica against pheretima posthuma. J. Pharm. Res. Int. 6:134-7.

Peiretti PG, 2010. Ensilability characteristics of chia (Salvia hispanica L.) during its growth cycle and fermentation pattern of its silages affected by wilting degrees. Cub. J. Agric. Sci. 44:33-6.

Peiretti PG, Gai F, 2009. Fatty acid and nutritive quality of chia (Salvia hispanica L.) seeds and plant during growth. Anim. Feed Sci. Technol. 148:267-75.

Peiretti PG, Meineri G, 2007. Fatty acids, chemical composition and organic matter digestibility of seeds and vegetative parts of false flax (Camelina sativa L.) after different lengths of growth. Anim. Feed Sci. Technol. 133:341-50.

Peiretti PG, Meineri G, 2008. Effects on growth performance, carcass characteristics, and the fat and meat fatty acid profile of rabbits fed diets with chia (Salvia hispanica L.) seed supplements. Meat Sci. 80:1116-21.

Peiretti PG, Meineri G, 2010. Effects of diets with increasing levels of golden flaxseed on carcass characteristics, meat quality and lipid traits of growing rabbits. Ital. J. Anim. Sci. 9:e70.

Perry L, Metzger J, 1980. Medicinal plants of East and Southeast Asia: attributed properties and uses. The MIT Press, Cambridge.

Reyes-Caudillo E, Tecante A, Valdivia-López MA, 2008. Dietary fibre content and antioxidant activity of phenolic compounds present in Mexican chia (Salvia hispanica L.) seeds. Food Chem. 107:656-63.

Rodríguez-Abello D, Ramírez-Avilés L, Navarro-Alberto J, Zamora-Bustillos R, 2016. Performance of growing rabbits fed increasing levels of discarded Salvia hispanica L. (chia) seed. Trop Anim Health Prod. 48:959-65.

Salazar-Vega MI, Rosado-Rubio JG, Chel-Guerrero LA, BetancurAncona DA, Castellanos-Ruelas AF, 2009. Composition in alpha linolenic acid ( 13 ) of egg and broiler meat using Chia (Salvia hispanica L.) in poultry feedstuff. Interciencia 34:20913.
Sandoval-Oliveros MR, Paredes-López O, 2013. Isolation and characterization of proteins from Chia seeds (Salvia hispanica L.). J. Agric. Food Chem. 61:193-201.

Schettino B, Vega S, Gutiérrez R, Escobar A, Romero J, Domínguez E, González-Ronquillo M, 2017. Fatty acid profile of goat milk in diets supplemented with chia seed (Salvia hispanica L.). J. Dairy Sci. 100:6256-65.

Sierra L, Roco J, Alarcon G, Medina M, Van Nieuwenhove C, de Bruno MP, Jerez S, 2015. Dietary intervention with Salvia hispanica (Chia) oil improves vascular function in rabbits under hypercholesterolaemic conditions. J. Funct. Foods. 14:641-9.

Silva BCE, dos Santos HMC, Montanher PF, Boeing JS, de Cinque Almeida V, Visentainer JV, 2014. Incorporation of omega-3 fatty acids in Nile tilapia (Oreochromis niloticus) fed chia (Salvia hispanica L.) bran. J. Am. Oil Chem. Soc. 91:429-37.

Silva S, Garrido M, Baginsky C, Valenzuela A, Morales L, Valenzuela C, Pavez S, Alister S, 2016. Effect of water availability on growth, water use efficiency and omega 3 (ALA) content in two phenotypes of chia (Salvia hispanica L.) established in the arid Mediterranean zone of Chile. Agric. Water Manag. 173:67-75.

Simopoulos AP, 2008. The importance of the omega-6/omega-3 fatty acid ratio in cardiovascular disease and other chronic diseases. Exp. Biol. Med. 233:674-88.

Simopoulos AP, 2016. An increase in the omega-6/omega-3 fatty acid ratio increases the risk for obesity. Nutrients 8:128.

Siscovick DS, Barringer TA, Fretts AM, Wu JH, Lichtenstein AH, Costello RB, Kris-Etherton PM, Jacobson TA, Engler MB, Alger HM, Appel LJ, 2017. Omega-3 polyunsaturated fatty acid (fish oil) supplementation and the prevention of clinical cardiovascular disease: a science advisory from the American Heart Association. Circulation CIR-0000000000000482.

Sprague M, Dick JR, Tocher DR, 2016. Impact of sustainable feeds on omega-3 long-chain fatty acid levels in farmed Atlantic salmon, 2006.2015. Sci. Reports 6:21892.

Steinmetz KA, Potter JD, 1996. Vegetables, fruit, and cancer prevention: a review. J. Am. Diet. Assoc. 96:1027-39.

Ting IP, Brown JH, Naqvi HH, Kumamoto J, Matsumura M, 1990. Chia: a potential oil crop for arid zones. In: Naqvi H.H., Estilai A., Ting I.P. (Eds.), Proceedings of the 1st International Conference of New Industrial Crops and Products. Riverside, CA, USA, pp. 197-202.

Tocher DR, 2015. Omega-3 long-chain polyunsaturated fatty acids and aquaculture in perspective. Aquaculture. 449:94-107.

Ullah R, Nadeem M, Khalique A, Imran M, Mehmood S, Javid A, Hussain J, 2016. Nutritional and therapeutic perspectives of Chia (Salvia hispanica L.): a review. J. Food Sci. Technol. 53:1750-8.

Urrutia O, Soret B, Insausti K, Mendizabal JA, Purroy A, Arana A, 2015. The effects of linseed or chia seed dietary supplementation on adipose tissue development, fatty acid composition, and lipogenic gene expression in lambs. Small. Ruminant Res. 123:204-11.

US Department of Agriculture, 2011. National Nutrient Database for Standard Reference, Release 24. Nutrient Data Laboratory Home Page. U.S. Department of Agriculture, Agricultural Research Service: Washington, DC, USA. Available from: http://www.ars.usda.gov/ba/bhnrc/ndl

US Department of Agriculture, 2004. Seeds, chia seeds, dried. Nutrient Database for Standard Reference, Release 27: Basic Report: 12006.

Valdivia-López MÁ, Tecante A, 2015. Chia (Salvia hispanica): a review of native Mexican seed and its nutritional and function- 
al properties. Adv. Food Nutr. Res. 75:53-75.

Vollmann J, Moritz T, Kargl C, Baumgartner S, Wagentristl H, 2007. Agronomic evaluation of camelina genotypes selected for seed quality characteristics. Ind. Crops Prod. 3:270-7.

Vuksan V, Whitham D, Sievenpiper JL, Jenkins AL, Rogovik AL, Bazinet RP, Vidgen E, Hanna A, 2007. Supplementation of conventional therapy with the novel grain Salba (Salvia hispanica L.) improves major and emerging cardiovascular risk factors in type 2 diabetes: results of a randomised controlled trial. Diabet. Care 30:2804-10.

Witkowska IM, Wever C, Gort G, Elgersma A, 2008. Effects of nitrogen rate and regrowth interval on perennial ryegrass fatty acid content during the growing season. Agron. J. 100:1371-9. Yeboah S, Owusu Danquah E, Lamptey JNL, Mochiah MB, Lamptey S, Oteng-Darko P, Adama I, Appiah-Kubi Z, Agyeman K, 2014. Influence of planting methods and density on performance of chia (Salvia hispanica) and its suitability as an oilseed plant. Agric. Sci. 2:14-26.

Zazpe I, Beunza JJ, Bes-Rastrollo M, Warnberg J, De La FuenteArrillaga C, Benito S, Vázquez Z, Martínez-González MA, 2011. Egg consumption and risk of cardiovascular disease in the SUN Project. Eur. J. Clin. Nutr. 65:676-82. 